\title{
A importância do apoio às exportações de setores estratégicos: uma análise do programa de incentivo exportador do BNDES nas últimas décadas
}

Danniele Giomo ${ }^{1}$

\begin{abstract}
Resumo: Este artigo procura avaliar qual o impacto do programa público de financiamento às exportações do BNDES (Banco Nacional de Desenvolvimento Econômico e Social) sobre as exportações brasileiras no período de 2000 a 2017. Para cumprir esse objetivo, o trabalho utilizou-se da metodologia econométrica de Métodos dos Momentos Generalizados (GMM) e as variáveis utilizadas foram: exportações brasileiras; crédito do BNDES; renda dos dez maiores parceiros (importadores) comerciais do Brasil; taxa de câmbio real efetiva e índice de preços de commodities. Também foram analisadas estatísticas descritivas como desembolso anual do sistema BNDES para exportação por setor CNAE e exportações brasileiras. As evidências sugerem que o programa BNDES tem impacto positivo e significativo sobre o valor total exportado, além de estar direcionando os recursos para os setores exportadores estratégicos para o desenvolvimento nacional.

Palavras-chave: Financiamento às exportações, BNDES.
\end{abstract}

Classificação JEL: O14.

The importance of supporting exports from strategic sectors: an analysis of the BNDES export incentive program in recent decades

\begin{abstract}
The article tries to evaluate the impact of the BNDES 'public export financing program on Brazilian exports from 2000 to the first quarter of 2017. In order to comply with the objective, the methodology was used Of Generalized Moment Methods (GMM) the variables used were: Brazilian exports; BNDES credit; Income of the ten largest commercial partners (importers) in Brazil; Effective real exchange rate and commodity price index. Descriptive statistics were also analyzed, such as the annual disbursement of the BNDES system for export by CNAE sector and Brazilian exports. The evidence suggests that the BNDES program has a positive and significant impact on the total exported value, as well as directing resources to the strategic export sectors for national development.
\end{abstract}

Keywords: Exports. Export financing, BNDES.

\section{Introdução}

O desenvolvimento econômico é puxado, dentre outras coisas, pela demanda, mas não basta uma demanda sustentada interna para haver crescimento, é preciso que essa demanda seja de maior alcance e isto é garantido pelas exportações por meio da demanda externa, segundo Bresser-Pereira et al (2016). Sendo assim, as exportações podem ser consideradas como um dos motores da economia.

As exportações brasileiras aumentaram expressivamente após o movimento de abertura comercial e das rodadas de negociações multilaterais efetuadas no âmbito da Organização Mundial do Comércio (OMC) na década de 1990. Além disso, o aumento da liquidez, proporcionado pelo crescimento da

1 Doutoranda em Economia pelo Instituto de Economia e Relações Internacionais da Universidade Federal de Uberlândia UFU - Uberlândia - MG. Mestre em Economia do Desenvolvimento pela Universidade Federal do Rio Grande do Sul UFRGS - Porto Alegre - RS. Graduada em Ciências Econômicas pelo IERI da Universidade Federal de Uberlândia - UFU Uberlândia - MG. E-mail: dannielegiomo@gmail.com 
economia mundial, reincorporou o país ao fluxo de capitais internacionais e favoreceu a expansão da oferta das linhas privadas de financiamento à atividade exportadora.

No entanto, apesar do cenário favorável às vendas externas, principalmente após a entrada no novo século, muitos obstáculos ainda permaneceram às exportações industriais brasileiras. Um dos principais desafios era aumentar a diversidade das exportações industriais, consolidando produtos brasileiros de setores diferenciados mais propensos à criação de valor para a economia, que contribuem com a expansão de emprego e renda, com o crescimento sustentado de longo prazo, com a geração de divisas e com a manutenção do equilíbrio do balanço de pagamentos.

Nesse contexto, o sistema nacional de apoio à exportação tornou-se fundamental na estratégia de desenvolvimento e passou por uma reformulação em meados dos anos 1990. Atualmente, a política de promoção de exportação conta com diversas frentes de atuação, que são coordenadas por diversos órgãos, e dispõe de programas específicos para incrementar a competitividade institucional e operacional da produção exportável, comercial, financeira e a eficiência das negociações comerciais. Os programas destinados à competitividade financeira incluem mecanismos de concessão de garantias e seguros, além de financiamento às exportações, sendo esse último o objeto de estudo deste artigo.

O sistema de financiamento à exportação atua na provisão de recursos aos exportadores, viabilizando a produção exportável no período entre a recepção da ordem de exportação e o pagamento das mercadorias pelo importador. O exportador, normalmente, necessita de recursos para realizar a produção em tempo hábil e de acordo com o contrato de vendas. Também pode precisar da antecipação dos recursos que serão pagos pelo importador em determinado momento do tempo.

Os financiamentos às exportações são disponibilizados tanto na rede pública quanto na rede privada. O acesso dos exportadores aos recursos privados depende de vários fatores, tais como da relação banco-cliente, da constituição de garantias patrimoniais, do montante da operação, dentre outros. Por essa razão, muitas empresas não conseguem obter recursos suficientes para financiar sua produção exportável e muitas perdas podem resultar dessa distorção de mercado. Nesse caso, a atuação do Estado é capaz de produzir um arranjo favorável à manutenção do crescimento econômico, ao estimular mais empresas com potencial exportador a entrar no mercado internacional.

Além da melhoria de acesso aos recursos pelas empresas exportadoras em geral, o apoio às exportações pelo Estado, sendo integrado a uma visão estratégica de desenvolvimento de longo prazo e articulado às políticas industriais e tecnológicas, mostra-se um caminho fértil ao crescimento econômico. Para isto, a política estratégica deve ser mais a de direcionamento de recursos a setores industriais mais complexos, de maior encadeamento e geração de valor, do que aos setores de menos agregação tecnológica, nos quais o Brasil atualmente se especializa cada vez mais. Os diversos setores industriais são capazes de alavancar maiores taxas de crescimento para a economia em razão das características da elasticidade-renda de seus produtos e das oportunidades tecnológicas que esses setores possuem.

As agências de crédito à exportação dos países desenvolvidos apresentaram características distintas em relação à ênfase dos mecanismos de apoio utilizados em comparação com os países emergentes. Os países desenvolvidos, que possuem um sistema financeiro mais maduro, priorizam as operações de concessão de garantias e seguros à atividade exportadora. Isso indica que a maior parte dos recursos para financiamento é obtida no mercado privado e que as concessões de garantias e seguros são uma questão mais difícil para se resolver, mesmo para os países mais ricos. Por sua vez, as agências de apoio à exportação dos países em desenvolvimento, como o Brasil, concentram seus esforços, principalmente, na oferta de recursos para financiar as vendas externas, complementando seus mercados financeiros privados, que não possuem capacidade para disponibilizar todos os recursos demandados.

Quando as ações governamentais estão ajustadas às estratégias de expansão das vendas a outros mercados, normalmente isso afeta positivamente a cadeia produtiva. $\mathrm{O}$ desenvolvimento de um setor exportador mais dinâmico e integrado ao comércio mundial, dada a sua capacidade de transbordamento, atende também ao objetivo de fortalecer o mercado interno, pois funciona como poderoso instrumento catalisador para a elevação da produtividade e eficiência das empresas do país. 
A hipótese deste trabalho é que o apoio do BNDES às exportações por meio do crédito causa um impacto positivo e significante no total das exportações brasileiras e procura impulsionar setores estratégicos da estrutura produtiva do país no desenvolvimento nacional, ou seja, os créditos de apoio à exportação fornecidos pelo Banco Nacional do Desenvolvimento Econômico e Social (BNDES) às empresas, entre o primeiro trimestre de 2000 e o primeiro trimestre de 2017 , impactaram positivamente a pauta exportadora brasileira.

Esta pesquisa se justifica pela recente política governamental de cortes de recursos e ações do BNDES como parte de uma política fiscal e monetária contracionista em vigor atualmente no Brasil. Dada a grande importância da inserção comercial externa e suas características estruturais para o processo de desenvolvimento econômico, faz-se necessário conhecer o impacto dos incentivos para a exportação do BNDES no comércio internacional. É imprescindível conhecer a relevância dos estímulos do programa do BNDES sobre as exportações para verificar a dimensão do prejuízo dessa política restritiva ao desenvolvimento econômico brasileiro. É nesse contexto que este trabalho foi desenvolvido e seu objetivo principal é mensurar o impacto da variação dos créditos do BNDES sobre as exportações brasileiras de 2000 a 2017.

Procurou-se avaliar aqui qual o impacto do programa público de financiamento às exportações do BNDES sobre as exportações brasileiras no período de 2000 a 2017. Para cumprir esse objetivo, utilizouse a metodologia dos Mínimos Quadrados Ordinários (MQO), de Métodos dos Momentos Generalizados (GMM) e as variáveis usadas para os modelos econométricos foram: exportações brasileiras; crédito do BNDES; renda dos dez maiores parceiros (importadores) comerciais do Brasil; taxa de câmbio real efetiva e índice de preços de commodities. Também foram analisadas estatísticas descritivas, como desembolso anual do sistema BNDES para exportação por setor CNAE e para exportações brasileiras. As evidências sugerem que o programa do BNDES tem impacto positivo e significativo sobre o valor total exportado, além de estar direcionando os recursos para os setores exportadores estratégicos para o desenvolvimento nacional.

Esta introdução é a primeira parte deste artigo. Ele ainda é composto pela revisão bibliográfica, por análises descritivas sobre as características e os direcionamentos do programa BNDES-Exim, pela avaliação do impacto do programa sobre as exportações brasileiras por meio de modelos econométricos e, finalmente, pelas considerações finais.

\section{Revisão Bibliográfica}

Apesar de os benefícios gerados pela participação de um país no comércio internacional serem reconhecidos há muito tempo pela teoria econômica, existem diferentes visões sobre eles. Em geral, há pelo menos duas formas opostas de relacionar crescimento econômico, especialização produtiva comercial e comércio internacional. De um lado, estão as tradições clássica e neoclássica explicando que o livre comércio induz a especialização de países de acordo com perfis de eficiência produtiva desiguais e complementares, levando-os a maximizar a riqueza com os recursos e as capacitações existentes. De outro, tradições heterodoxas, dentre elas a estruturalista, alegam que a existência de especializações produtivas tende a provocar interações comerciais assimétricas, com efeito desigual sobre a capacidade de geração de riqueza e acumulação de capacitações produtivas entre os países (MOREIRA, 2012). O estruturalismo, ao analisar a dinâmica da economia internacional, por meio da Divisão Internacional do Trabalho, trata a estrutura produtiva periférica como especializada e heterogênea e, por outro lado, a do centro como diversificada e homogênea (RODRÍGUEZ, 2009).

Segundo Smith (1776 [1985]), o livre comércio seria um poderoso mecanismo capaz de promover o aumento da produção por meio da especialização e, com trocas, aumentar o consumo e, consequentemente, o bem-estar das populações dos países que participam do comércio internacional, denominado nessa teoria como benefícios ou ganhos do comércio. Posteriormente, David Ricardo formulou a teoria tradicional do comércio amparada no ideário das vantagens comparativas. Esse princípio se apoia na vantagem comparativa que determinado país possui em relação a outro na fabricação de determinado produto, beneficiando-se com a especialização na produção desses bens, 
obtendo os demais por intermédio da importação. Dessa forma, o comércio internacional seria uma forma de melhorar a eficiência da alocação de recursos em termos internacionais.

A teoria tradicional do comércio baseada nas vantagens comparativas afirma que as mercadorias ofertadas por um país no mercado internacional consistem no que de melhor e mais eficiente que os trabalhadores e os recursos dessa economia são capazes de realizar e são trocadas pelo que as demais economias produzem de melhor. Além dos ganhos de eficiência derivados da especialização, a intensificação da concorrência advinda do aumento do comércio exterior traria benefícios à sociedade ao excluir as firmas ineficientes do mercado. Dessa forma, produtos de melhor qualidade a preços adequados são selecionados e chegam aos consumidores de uma forma que não aconteceria se os mercados locais fossem inacessíveis para as firmas estrangeiras. Além disso, a concorrência aprimoraria a qualidade, a precisão e ajustaria as características do produto em consonância com as preferências de consumidores e compradores industriais.

Opostamente à teoria do livre comércio, o estruturalismo defende que, na periferia mundial, a especialização e o seu padrão de industrialização trazem consigo um ritmo de progresso técnico lento, de tal modo que as dificuldades de alcançar graus altos de complementaridade interssetorial e integração vertical da produção se tornam limitantes para um crescimento de longo prazo. Esses fatores fazem com que ocorram aumentos na demanda de importações de bens que não podem ser produzidos internamente, tendendo assim a superar as exportações, levando ao déficit comercial, a desequilíbrios da balança comercial e, consequentemente, a desequilíbrios externos limitantes que alternam os períodos de bonança e de aguda escassez.

Rodrik (2006) tem uma visão baseada na diferenciação setorial e apresenta argumentos opostos aos da teoria tradicional do comércio. Para ele, o sucesso no desenvolvimento econômico exige diversificação produtiva e não especialização em poucos produtos. Tal desempenho depende de outros elementos, como as escolhas de política econômica. Além do desempenho diferenciado entre as empresas exportadoras e não exportadoras, a diferenciação setorial reforça o papel das exportações como um dos motores de desenvolvimento econômico. Trata-se da diferenciação existente entre os diversos setores industriais, que não são equivalentes entre si em relação à capacidade de crescimento e geração de empregos, renda e riqueza.

Thirlwall (1983), em seu trabalho A plainman's guide to Kaldor's growth laws, destaca que, para Kaldor, quanto mais rápida for a taxa de crescimento do setor industrial, mais rápida será a taxa de crescimento do Produto Interno Bruto (PIB). Ainda segundo essa teoria, a demanda por produtos industriais é muito elástica no estágio intermediário de desenvolvimento e continua quando atinge a maturidade. Por isso não há restrições sobre crescimento nesse setor. Mas seja qual for a demanda por commodities, o crescimento pode se enfraquecer por restrições de oferta, pode haver uma restrição de trabalho e/ou uma restrição de mercadorias.

As diferentes visões sobre a importância das exportações têm implicações diretas nas escolhas de política comercial a ser adotada por um país ou região. Uma estratégia de comércio baseada na teoria de vantagens comparativas enfatiza mais fortemente as medidas de apoio geral ao comércio exterior, promovendo maior abertura comercial e diminuição dos entraves à livre circulação de mercadorias, como redução das tarifas e das barreiras não tarifárias. Por sua vez, as políticas baseadas na compreensão de que o setor externo é capaz de gerar vantagens para as empresas exportadoras e que o desempenho setorial diferenciado é fundamental para o desenvolvimento econômico estão mais propensas a atuar de maneira estratégica e coordenada, apoiando setores específicos e fortalecendo cadeias produtivas. E é justamente pela importância das exportações que os mecanismos de fomento às exportações ganham relevância.

A promoção das exportações vem sendo usada em países industrializados desde o começo do século XX (SERINGHAUS; BOTSCHEN, 1991). Naidu et al. (1997) destacam que países que se tornaram industrializados nas últimas décadas do século passado, como Hong Kong, Taiwan, Singapura e Coreia do Sul, demonstraram o poder que tal política pode ter. O fortalecimento do compromisso com a assistência à exportação e com o estabelecimento de programas para aumentar a atividade exportadora das firmas é parte das políticas públicas de quase todos os países desenvolvidos e em desenvolvimento. Nas últimas décadas, não apenas houve aumento dos valores dedicados pelos governos a essas ações 
como, de acordo com Galetti (2010), o número de agências de apoio à exportação triplicou no contexto do desenvolvimento de estratégias nacionais de exportações em todo o mundo.

A relevância da ação governamental no incentivo às exportações foi discutida por Hausmann e Rodrik (2003). Eles chamam a atenção para a importância que as decisões de investimento corretas têm no processo de desenvolvimento econômico e que os governos precisam atuar para promover o crescimento industrial e a transformação estrutural. Sob essa ótica, algumas formas de atuação governamental no apoio às exportações, como os empréstimos e as garantias, seriam capazes de agir para esses objetivos.

As "políticas de promoção de exportação" são medidas de políticas públicas que realmente, ou potencialmente, incrementam a atividade exportadora na empresa, na indústria ou em nível nacional. A política de promoção à exportação brasileira conta com programas destinados a incrementar a competitividade financeira da atividade exportadora por meio de linhas de financiamento, concessão de seguros à exportação e fundos de aval para a concessão de garantias aos exportadores (PIANTO; CHANG, 2006).

Considerando a importância das exportações para o crescimento econômico, o sistema de financiamento à exportação é fundamental pela disponibilidade de recursos,pela questão do acesso a eles pelas empresas exportadoras e como componente estratégico de uma política comercial articulada com as políticas tecnológica e industrial, todas inseridas num contexto mais amplo de uma política de desenvolvimento coordenada pelo Estado. Essa posição não significa que a participação dos agentes privados deva ser relegada a um segundo plano ou que exista intervenção do Estado nos assuntos de ordem privada. Significa, tão somente, identificar o Estado como agente essencial no processo de desenvolvimento, aproveitando as qualificações do setor privado de modo a dividir tarefas importantes entre si (GALETTI; HIRATUKA, 2013).

Veiga e Iglesias (2002) dizem que os mecanismos públicos são essenciais no suprimento de financiamento para bens com ciclos longos de produção e comercialização. Em outra perspectiva, na visão de Blumenschein e De Leon (2002), as razões apontadas para a intervenção do governo no mercado de crédito e seguro à exportação estariam ligadas aos ganhos de uma política industrial resultantes do poder de mercado no comércio internacional, além do aumento de divisas e da geração de empregos decorrentes do aumento do volume de exportações.

Nas opiniões de Garófalo e Teixeira (1995) em pesquisas sobre comércio internacional, constatase a necessidade de financiamento como fator decisivo para a competitividade dos produtos, bens ou serviços a serem exportados e reconhece-se também o fato de que a participação dos governos, por meio de aportes de recursos públicos, é inversamente proporcional ao grau de desenvolvimento do país analisado. Sendo assim, a presença do Estado se faz mais forte quanto mais frágil é a economia. Argumentam que a ação estatal é diretamente proporcional às fragilidades e insuficiências dos mercados e ao atraso relativo de cada país diante da fronteira tecno-produtiva. Isso explicaria a maior presença econômica do Estado nos países de desenvolvimento retardatário.

O trabalho de Cunha et al. (2016) sugere que o crédito originado nos bancos estatais mostra características anticíclicas, enquanto bancos privados se comportam de uma maneira pró-cíclica. O relatório da UNCTAD (2016) mostra que os bancos estatais brasileiros teriam agido de forma contracíclica em resposta à crise financeira global de 2008. Porém a atuação dos bancos estatais não é importante apenas nos períodos de crise, eles também desempenham papéis importantes durante os períodos de boom econômico, como a promoção estratégica de investimentos para o desenvolvimento econômico. Eles também realizam o papel fundamental de bancos de exportação-importação e esse papel não é exclusivo de países em desenvolvimento, como poderia ser esperado (UNCTAD, 2016).

O segmento de financiamento, garantia e seguro ao crédito à exportação do Brasil tem diversos agentes públicos atuantes, como o BNDES, o Banco do Brasil, vários bancos regionais e agentes financeiros credenciados ao BNDES e à Sociedade Brasileira de Crédito à Exportação (SBCE). Dessas instituições, o BNDES é o que atua mais fortemente na concessão de créditos para as atividades industriais em geral e para o financiamento à exportação, especificamente. Para o financiamento às vendas no exterior, a atuação dos agentes financeiros do setor privado é muito importante e responde pela maior parcela dos recursos disponíveis aos exportadores, de acordo com Galetti e Hiratuka (2013). 
Esses dois setores de financiamento são interdependentes, pois a maior disponibilidade de recursos privados concede maior autonomia ao setor público para atuar no crédito à exportação de forma estratégica e mais alinhada às diretrizes das políticas tecnológica e industrial. Por sua vez, a atuação estratégica e eficiente do setor público é capaz de aumentar a atratividade do financiamento à exportação para os agentes privados, de forma a expandir os recursos disponíveis. Desse modo, a disponibilidade dos recursos e a atuação estratégica seriam elementos que se reforçariam mutuamente.

A grande participação do mercado é fundamental para o financiamento às exportações brasileiras, pois abre espaços para que os programas públicos atuem de forma complementar, de modo a direcionar seus esforços para operações com prazos mais longos e valores mais altos, a apoiar a diversificação geográfica e produtiva, a viabilizar a participação das empresas de menor porte, além de promover a exportação de produtos de maior geração de valor. Em consonância com os objetivos de um programa de desenvolvimento econômico lastreado no incremento do comércio exterior, o Brasil apresenta um quadro positivo em relação à participação dos agentes financeiros do setor privado.

As firmas que mais utilizam as linhas privadas de financiamento são aquelas dos setores industriais de bens tradicionais, que apresentam as maiores vantagens comparativas, além do setor de veículos. Com isso, os programas públicos de financiamento podem se prestar ao auxílio dos setores de maior geração de valor (bens de capital), maior conteúdo tecnológico (eletrônicos, informática), de maior importância estratégica (biocombustíveis), entre outros (CNI, 2008).

Em uma economia moderna, as instituições financeiras têm um importante papel na oferta de crédito. Mas quando se trata do financiamento ao investimento produtivo de longo prazo, são grandes as dificuldades encontradas pelos empresários. Em geral, as instituições financeiras privadas não atuam na concessão desse tipo de crédito em razão dos riscos e das incertezas, dos baixos retornos, do grande volume de recursos e de maiores prazos de financiamento. Além disso, em muitos países, o mercado de capitais é insuficiente para atender ao volume da demanda de recursos das empresas. Daí o papel relevante exercido pelos bancos de desenvolvimento, os quais atuam visando atender as demandas não supridas pelo setor financeiro privado.

O BNDES, órgão subordinado ao Ministério do Desenvolvimento, Indústria e Comércio Exterior (MDIC), é um banco estatal e de desenvolvimento brasileiro. Ele foi criado para promover os financiamentos de longo prazo de projetos de investimentos, especialmente nos setores ligados à indústria e à infraestrutura. Sua missão é "promover o desenvolvimento sustentável e competitivo da economia brasileira, com geração de emprego e redução das desigualdades sociais e regionais", e sua visão é "Ser o banco do desenvolvimento do Brasil, instituição de excelência, inovadora e proativa ante os desafios da nossa sociedade" (BNDES, 2009).

Ele foi muito relevante quando o desempenho desfavorável das exportações, em um contexto de abertura na década de 1990, levou o governo a adotar algumas medidas para contrabalançar o aumento do déficit comercial. No âmbito dessas mudanças, o sistema de financiamento público à exportação foi alvo de um processo de remontagem com a criação das linhas de crédito geridas pelo BNDES e voltadas ao setor de bens de capital chamada Finamex. A partir de 1996, o programa passou por mudanças que incluíram outros setores de atuação, como produtos químicos, têxteis, eletrônicos, calçados, couros e alimentos, além dos serviços de engenharia. Os recursos vêm de fundos diversos, tais como o FAT (Fundo de Amparo ao Trabalhador) e linhas externas, inclusive de organismos multilaterais. Um dos objetivos da linha de financiamento à exportação do BNDES é ampliar a participação dos produtos de maior geração de valor no comércio exterior brasileiro (CATERMOL, 2005).

$\mathrm{O}$ recuo do setor privado brasileiro de fornecer financiamento de longo prazo para projetos de infraestrutura e indústria fez com que o BNDES, historicamente, concentrasse seus desembolsos nesses setores, uma tendência que continuou nas últimas décadas. Em 2004, o apoio às micro, pequenas e médias empresas (MPME) exportadoras passou a ter maior prioridade, a fim de apoiar as parcerias entre empresas de menor porte e as grandes empresas, que funcionam como empresas-âncoras. Em 2005, foram estabelecidas condições específicas para o apoio à exportação de veículos de passeio, com o objetivo de ajudar na consolidação da indústria automobilística nacional também como plataforma exportadora. Já em 2006, o BNDES criou uma linha de crédito voltada principalmente para as empresas 
produtoras de bens seriados, os quais são produzidos em larga escala e de forma padronizada, como máquinas agrícolas, tratores, ônibus e caminhões (WEBBER; DATHEIN, 2014).

No Brasil, a disponibilidade de crédito foi particularmente impactada pela crise de 2008 , com uma consequente queda líquida dos fluxos de capital para os mercados emergentes e a repatriação de investimentos. Como resultado, as instituições financeiras privadas nacionais e estrangeiras racionaram crédito para a indústria brasileira. Em vez de minimizar seu plano de política industrial, o governo brasileiro acelerou-o através do Programa de Sustentabilidade de Investimentos (PSI), que aumentou os incentivos fiscais e a disponibilidade de crédito, transferindo recursos do Tesouro ao BNDES (MAZZUCATO; PENNA, 2015).

De acordo com o BNDES, o banco tem consolidado sua posição de financiador das exportações brasileiras de bens e de serviços de engenharia e construção. Estão contemplados as exportações de bens e os serviços brasileiros para grandes projetos de infraestrutura física, voltados para o desenvolvimento econômico-social e para a integração da América Latina. São obras de construção de aquedutos, aeroportos, rodovias, metrôs, gasodutos, hidrelétricas e linhas de transmissão de energia elétrica em diferentes países. $\mathrm{O}$ banco financia exclusivamente a parcela de bens e serviços brasileiros envolvidos em cada projeto. Por trás desses financiamentos, estão produtos brasileiros de alto valor agregado, sobretudo bens de capital, que compõem o conjunto das exportações de serviços de engenharia e construção. As operações podem ser feitas diretamente com o BNDES ou por intermédio da rede de agentes financeiros credenciados.

O financiamento, realizado por meio das linhas BNDES Exim Pré-Embarque e Pós-Embarque, tem por objetivo o fortalecimento da indústria, a geração de emprego, renda e divisas no Brasil. O financiamento à produção (Pré-Embarque) fornece recursos em prazos adequados ao ciclo de produção da empresa que irá exportar. É representado pelo capital de giro que o exportador irá utilizar na compra de matéria-prima e contratação de mão de obra para a produção dos bens a serem exportados.

$\mathrm{O}$ financiamento à comercialização (Pós-Embarque) permite que a empresa financie seu importador e receba os recursos à vista, depois de comprovada a exportação. $\mathrm{O}$ apoio possibilita que a empresa possa competir internacionalmente com prazos de pagamento mais longos, sem onerar sua estrutura financeira.

O BNDES Exim é formado por três diferentes modalidades de financiamentos que se ramificam em diferentes linhas. Nas linhas da modalidade Exim Pré-Embarque, o financiamento é destinado à produção dos bens e aos serviços destinados à exportação. Esse apoio conta com a intermediação de um agente financeiro credenciado ao BNDES, em geral bancos comerciais com os quais o exportador já mantém relacionamento e que são os tomadores do risco de crédito do exportador perante o BNDES. As modalidades Exim Pré-Embarque são:

a) BNDES Exim Pré-embarque: financiamento à produção nacional de máquinas, equipamentos, bens de consumo, entre outros bens e serviços, para exportação;

b) BNDES Exim Pré-embarque Empresa Âncora: financiamento à exportação de bens e serviços, efetuada por intermédio de uma empresa âncora, assim consideradas as trading companies, empresas comerciais exportadoras e demais empresas exportadoras que participem da cadeia produtiva e que adquiram a produção de outras empresas para exportação;

c) BNDES Exim Pré-embarque Empresa Inovadora: financiamento a empresas com perfil inovador para a exportação de bens de capital e serviços de tecnologia da informação (TI) desenvolvidos no Brasil.

Já a modalidade Exim Pós-Embarque é formada por linhas de operações diretas realizadas por intermédio de bancos mandatários no Brasil. No produto pós-embarque, o objeto do financiamento é a comercialização de bens e serviços brasileiros. Nesse caso, o BNDES antecipa à empresa brasileira exportadora o valor dos bens ou serviços devidos pelo importador estrangeiro. Esse desembolso de recursos se dá em reais no Brasil, e o importador estrangeiro passa a dever ao BNDES. Portanto, não há remessa de divisas ao exterior. O pagamento do financiamento pelo importador estrangeiro é realizado por intermédio de banco mandatário, que, entre outras atribuições, fecha o câmbio e repassa o valor em reais ao BNDES. As linhas do Exim Pós-Embarque são: 
a) BNDES Exim Pós-embarque Bens: financiamento à exportação de bens de fabricação nacional, como máquinas, equipamentos, bens de consumo e serviços a eles associados;

b) BNDES Exim Pós-embarque Serviços: financiamento à exportação de serviços nacionais, como construção civil, serviços de engenharia e arquitetura, de tecnologia de informação, entre outros. Inclui os bens de fabricação nacional a serem utilizados e/ou incorporados ao empreendimento;

c) BNDES Exim Aeronaves: financiamento à exportação de aeronaves e motores aeronáuticos civis, bem como partes, peças e serviços associados - todos de fabricação nacional.

\section{Análise Descritiva: características e direcionamentos do programa BNDES Exim}

Como foi abordado na literatura deste trabalho, é importante que os recursos de financiamento das exportações sejam direcionados para os setores mais dinâmicos da economia, com maior agregação de valor, capacidade de transbordamento e encadeamento. A perspectiva teórica subjacente a este trabalho sugere que o tipo de bem em que um país se especializa tem importantes implicações para o seu desempenho econômico subsequente: tudo o mais constante, uma economia é melhor produzindo bens que países ricos exportam, reforçando assim a importância de que o governo atue para que as suas exportações priorizem em sua pauta os bens associados à alta produtividade. Pelos aspectos citados, parece ser clara a necessidade de uma política industrial e a busca pela inserção comercial externa por meio de produtos com maior conteúdo tecnológico.

As exportações do Brasil se expandiram consideravelmente ao longo dos anos 200o, cerca de $10 \%$ a.a. em média. Além disso, de acordo com o Gráfico 1, em todos os setores houve expansão das suas exportações ao longo do período analisado. Contudo o crescimento das exportações nos setores em geral não foi linear em todos os anos da série, tendo variações negativas como consequência da crise. Em 2009, todos os setores viram as suas vendas caírem bruscamente, com destaque para o de média intensidade tecnológica, com queda de $40 \%$ em relação ao ano anterior. 
Gráfico 1: Evolução das exportações brasileiras por intensidade tecnológica, segundo a metodologia de Lall², 2000-2017, em bilhões de dólares

$\$ 100$

$\$ 90$

$\$ 80$

$\$ 70$

$\$ 60$

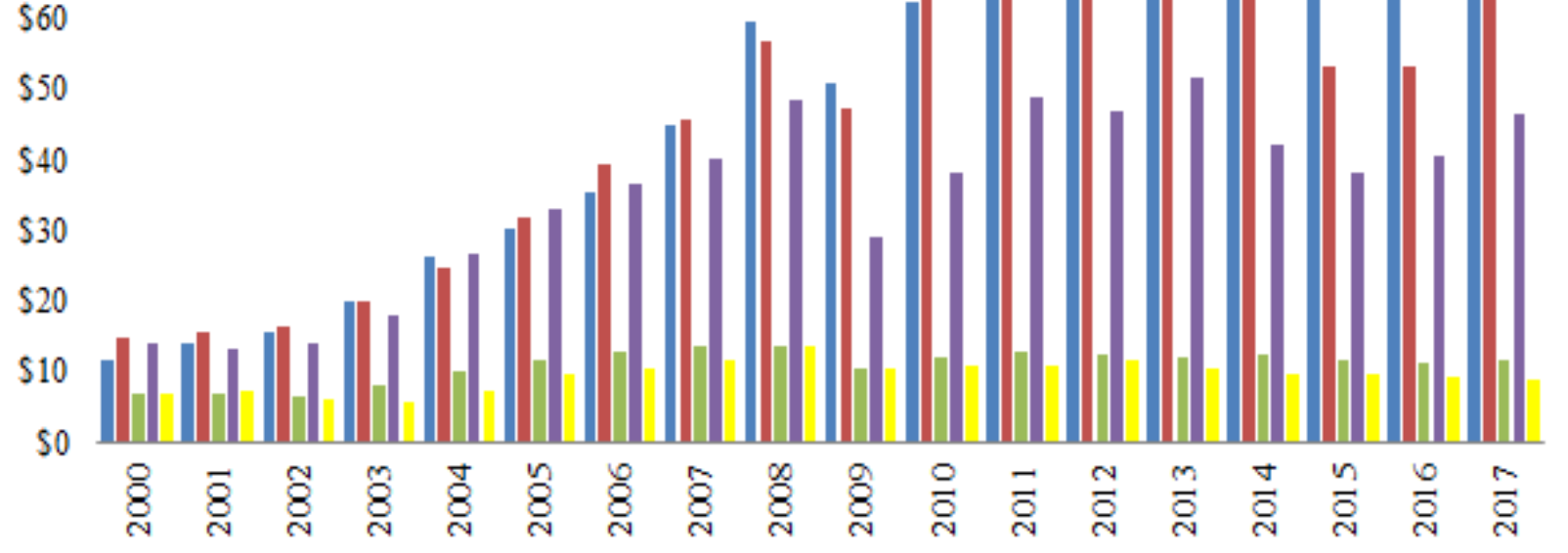

- Produtos Primários

- Baix a Intensidade Tecnol ógica

\section{- Alta Intensidade Tecnológica}

Fonte: UNCOMTRADE. Elaboração própria.

O setor de produtos primários, nos anos finais da série, foi o que conseguiu maior peso na pauta de exportações brasileiras e, além disso, obteve um crescimento em média de 14\% a.a. entre 2000-2017. O segundo setor de maior contribuição nas exportações do Brasil é o de manufaturas intensivas em recursos naturais e trabalho, que alcançou um crescimento médio de $11 \%$ a.a. ao longo dos anos pesquisados. Esses dois setores chamam atenção pela inversão de suas participações na pauta de exportação nos anos de impacto da crise, 2008 e 2009, e também na pós-crise até o último ano da série observada, 2017. No imediato pós-crise, 2010 e 2011, o setor de manufaturas intensivas em recursos naturais e trabalho é quem assume a posição de liderança na pauta exportadora brasileira; em seguida, os produtos primários encabeçam esse ranking, com destaque pelo último quadriênio em que esse setor desponta.

Nos anos 2008 e 2009, esse aumento nas receitas de exportações de produtos primários se deve ao aumento de preços das commodities primárias e não a um aumento da quantidade exportada, já que em 2008 o crescimento dessa quantidade exportada, medida em toneladas, foi negativo, de 3,6\% a.a., e dos preços foi positivo, de 32\% a.a. Contudo, nos anos 2012 e 2013, a expansão decorre apenas do aumento da quantidade exportada, visto que as receitas das exportações crescem somente $1,4 \%$ em 2012 e decrescem $2,3 \%$ em 2013, e mesmo assim a quantidade cresce $7 \%$ e $6 \%$, respectivamente, o que confirma uma queda brusca nos preços.

Em 2015, sofrendo com os impactos da crise política e econômica, o setor de produtos primários também viu suas vendas ao exterior caírem, com a queda da receita de cerca de $12 \%$ em relação ao ano anterior, da quantidade, em toneladas, de $9 \%$ a.a. Em 2016, caiu tanto a receita quanto a quantidade em $10 \%$ a.a., e em 2017 houve uma reversão, com aumento expressivo de $17 \%$ a.a. da quantidade vendida ao exterior de produtos primários e de $22 \%$ em receitas.

\footnotetext{
${ }^{2}$ A Metodologia de Lall (200o) de agregação de dados, que será utilizada para agrupar os dados referentes às relações de comércio exterior do Brasil, foi construída por meio das metodologias de Pavitt (1984) e OCDE.
} 
O setor de manufaturas de média intensidade tecnológica apresentou crescimento médio da receita das vendas ao exterior de $9,5 \%$ a.a. ao longo da análise. Até 2008 , a taxa de crescimento anual média dessas exportações era de cerca de 18\%. Em 2009, as exportações do setor decresceram em 40\% a.a. Em 2012, 2014 e 2015 também tiveram resultados negativos nas taxas de crescimento, sendo -3\%, $19 \%$ e $-9 \%$, respectivamente. Esse setor é importante para o Brasil porque, dentre os maiores exportadores do país, é o que possui maior valor agregado nos seus produtos. Ele se destaca na exportação de ferro e formas de aço, peças para veículos, caminhões, veículos, navios e barcos. $\mathrm{O}$ ano de destaque nas exportações desse importante setor, que abarca os bens de capital, foi 2013, com vendas no valor de 51,6 bilhões de dólares.

O setor de alta intensidade tecnológica do Brasil alcançou um crescimento médio relevante de $5 \%$ a.a. nas exportações até 2012, valor bastante inferior aos outros setores. Entretanto, depois desse período ele apresentou somente taxas de crescimento negativas, uma média de $-5 \%$ a.a. de 2013 a 2017 . O maior valor exportado foi em 2008, 13,6 bilhões de dólares. Por outro lado, a menor venda ao exterior foi de 5 bilhões de dólares em 2003; esse período também apresentava crescimento negativo. Apenas em metade dos anos aqui estudados (2001, 2004, 2005, 2006, 2007, 2008, 2010, 2011 e 2012) esse setor obteve taxas de crescimentos positivas. A taxa de crescimento média de 2000 a 2017 foi, portanto, baixa - cerca de $2 \%$ a.a. O setor de baixa intensidade tecnológica tem comportamento semelhante no que se refere ao nível de valores exportados e de crescimento relativo médio das exportações. Este teve seu auge em 2008, exportando 13,6 bilhões de dólares. Logo em seguida, em 2009, o valor caiu para 10,2 bilhões de dólares, uma queda de cerca de $25 \%$ a.a. nas vendas para o exterior. O setor não conseguiu se recuperar e voltar ao patamar de vendas de 2008; o ano que esteve mais próximo a esse nível foi 2011, com cerca de 12,9 bilhões de dólares. Posteriormente apresentaram-se crescimentos negativos em 2017, e após uma pequena retomada no crescimento, alcançou-se o valor de 11,5 bilhões de dólares.

Como foi apresentada, a pauta exportadora brasileira pode ser caracterizada como de baixo dinamismo e concentrada em commodities tanto agrícolas quanto industriais. Nas commodities, os setores que mais contribuem com os saldos exportados são o de extração mineral e agropecuária, setores esses que foram beneficiados, principalmente, pela alta dos preços internacionais e pela expressiva e crescente demanda chinesa. $O$ setor siderúrgico é o destaque do grupo de baixa intensidade tecnológica.

O segmento de média intensidade, no âmbito da indústria de transformação, obteve ganhos expressivos de competitividade. Isso se deve aos setores de veículos automotores, ferroviário, máquinas e tratores, motos e móveis. Já o grupo de alta intensidade tecnológica desponta com o setor de aviação.

A queda na participação relativa desse setor, assim como nos de média e baixa intensidades tecnológicas, de crescimento dos setores de produtos primários e de manufaturas intensivas em recursos naturais e trabalho pode indicar, como destacaram Nascimento, Cardozo e Cunha (2009), que o Brasil não foi capaz de eliminar sua dependência de saldos comerciais gerados por commodities, e que as transformações nas últimas décadas conduziram a um aprofundamento da referida dependência.

Essa dependência também pode ser inferida ao se observar os dez principais importadores dos produtos brasileiros: Estados Unidos, China, Argentina, Países Baixos, Japão, Alemanha, Venezuela, Coréia do Sul, Chile e México. Esses importadores, em geral, importam do Brasil, majoritariamente, produtos primários e manufaturas intensivas em recursos naturais (SECEX/MDIC, 2013). Além disso, deve-se expor o impacto da inserção comercial da China no mercado internacional para o Brasil; ela era a terceira maior importadora brasileira já em 2006, e a partir de 2008 reforça ainda mais a sua importância para a pauta de exportações brasileira, tornando-se a principal importadora, sendo em sua maioria aquisições de produtos primários e manufaturas intensivas em recursos naturais.

Diante do exposto sobre as exportações brasileiras no século 21, o objetivo desta seção é verificar se a hipótese deste trabalho, de que o programa BNDES-Exim impulsiona os setores estratégicos da economia brasileira, é verdadeira e se o BNDES está conseguindo cumprir com o objetivo do seu projeto. Para isso, é importante analisar quais os setores, e em que magnitude, eles estão sendo beneficiados com os recursos do BNDES.

O gráfico abaixo traz a dinâmica das exportações brasileiras e do crédito às exportações do BNDES nos anos 2000. Nele, também pode ser analisada a proporção do crédito e das exportações totais 
brasileiras. A proporção entre o valor das exportações totais do Brasil em relação ao crédito de incentivo às exportações desembolsadas pelo BNDES é muito baixa, tendo seu ápice em 2010, quando o desembolso pelo BNDES-Exim foi $5,57 \%$ do valor total das exportações brasileiras.

Gráfico 2: Evolução anual das exportações brasileiras e do financiamento às exportações pelo BNDES de 2000 a 2017, em bilhões de dólares.

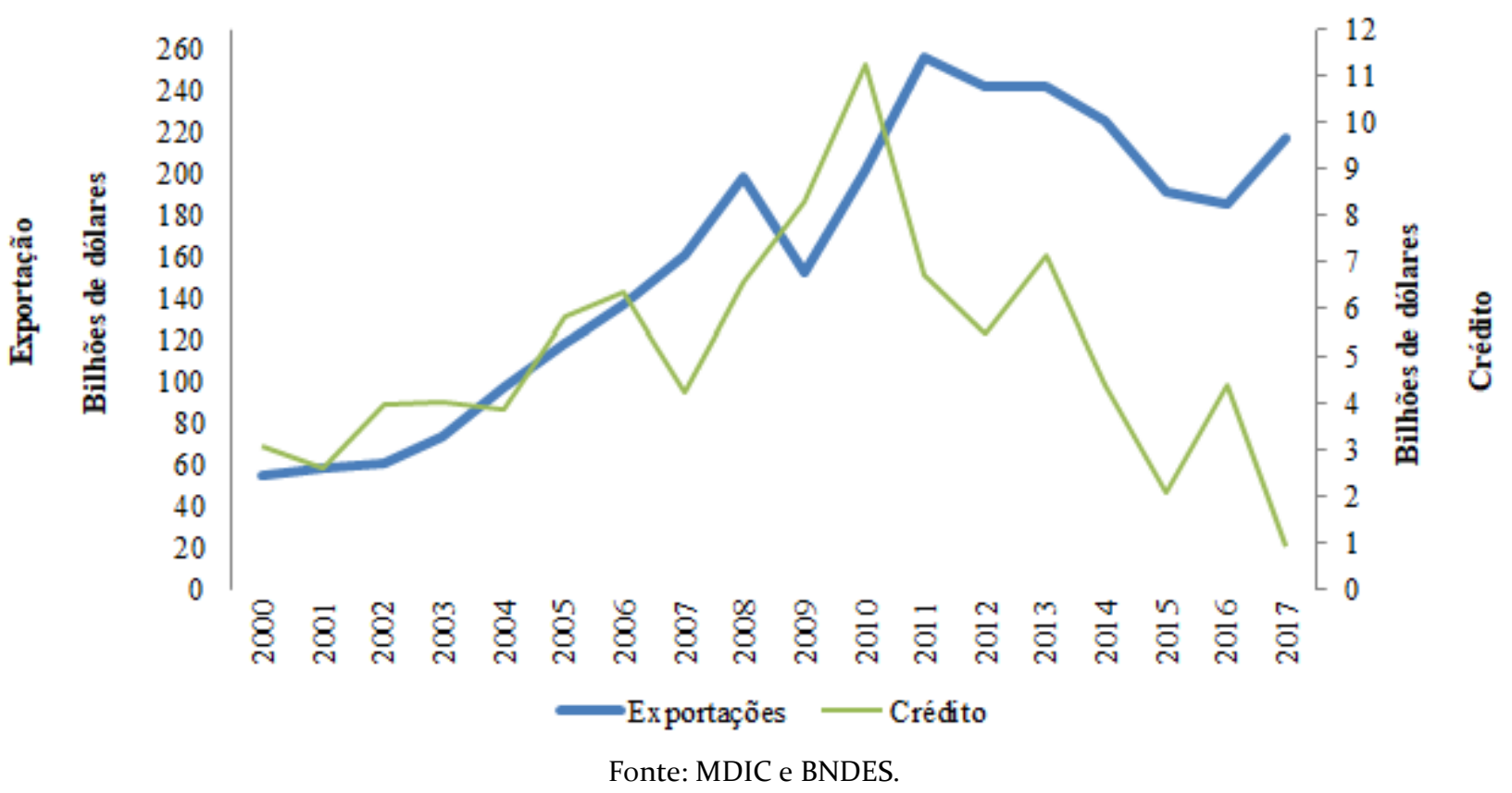

Em 2011, mesmo as exportações tendo seu ápice dos anos 2000, com mais de 256 bilhões de dólares exportados, a proporcionalidade entre o crédito e o total das exportações brasileiras caiu para 2,6\%. A partir desse ano essa magnitude esteve em trajetória de queda, chegando a 1,09\% em 2015. Esses dados mostram que, mesmo com a baixa nas exportações nos últimos anos, esse mecanismo de apoio à melhoria das exportações caiu, o que contraria o objetivo de suporte e melhoria das exportações com vistas ao desenvolvimento econômico proposto pelo BNDES-Exim. Além disso, em 2017, as exportações brasileiras voltaram a crescer e alcançaram um valor superior após dois anos de quedas bruscas, porém o valor financiado pelo BNDES-Exim em relação às exportações é de $0,4 \%$, evidenciando a ínfima participação do programa em 2017, com o menor valor de todo o período analisado, 932 milhões de dólares, como ilustrado no Gráfico 2.

Com exceção de 2017, em todo o período analisado foi ultrapassado o valor de US\$ 2 bilhões em desembolsos pelo BNDES para financiamentos às exportações, com um crescimento anual médio de $14 \%$. Como parte de uma política anticíclica houve um aumento de $26 \%$ em 2009 e de $70 \%$ em 2010 nos desembolsos de apoio à exportação do BNDES em relação a 2008, o ano da crise. Nos anos de 2009, 2010 e 2013 esses valores foram disponibilizados em nível recorde de todo o período analisado, 8, 11 e 7 bilhões de dólares, respectivamente. Esse aumento se deu tanto pelo esforço anticíclico do banco de desenvolvimento quanto pela migração da demanda dos mecanismos privados para o BNDES-Exim. A variação ao longo dos anos retrata o papel anticíclico do apoio às exportações pelo BNDES. Nos anos de menor disponibilidade de crédito privado, a participação do banco aumentou.

O BNDES, durante o período aqui analisado, possuiu vários programas de financiamentos. Os valores destinados a esses programas apresentaram tendência de crescimento, inclusive nos anos afetados pela crise mundial de 2008, porém em 2011 e 2015 tiveram uma baixa significativa, que se agravou nos dois últimos anos, 2016 e 2017. 
Em 2003, o valor com os desembolsos do BNDES-Exim foi o que mais se aproximou em relação aos desembolsos totais do BNDES com seus programas entre 2000 a 2017 - cerca de $44 \%$ dos empréstimos foram destinados a ele, embora este e aquele valor tenham sido baixos nesse ano: 33 bilhões de reais em desembolsos totais e cerca de 14 bilhões de reais com o programa exportador. Por outro lado, a menor participação se deu em 2014, sendo 12\% do total de 187 bilhões de reais, ou seja, 21 bilhões de reais. $\mathrm{O}$ aporte direcionado para essas linhas de financiamento teve seu máximo valor em 2013 em cerca de 190 bilhões de reais. Nesse mesmo ano, o valor do BNDES-Exim foi de aproximadamente 30 bilhões de reais, segundo dados do BNDES, compondo $16 \%$ do total dos desembolsos do BNDES com seus programas de financiamento. Em 2017, embora a proporção não tenha sido uma das menores, ambos os desembolsos caíram drasticamente, sendo 70 bilhões de reais os desembolsos totais e $26 \%$ desse valor, cerca de 18 bilhões de reais, os desembolsos com o programa BNDES-Exim.

Em relação às linhas de crédito pertencentes ao programa BNDES-Exim, a linha pré-embarque, no acumulado dos anos 2000, foi superior a $37 \%$ à do pós-embarque. O valor destinado a pré-embarque foi 117 bilhões de dólares. Embora essa linha tenha sido superior no recebimento dos desembolsos do BNDES-Exim na maioria dos anos estudados, até 2004 e em 2014, 2015 e 2017, a linha pós-embarque, por exemplo, a superou. Essa inversão pode ser explicada, entre outras coisas, pela linha pré-embarque financiar a produção para a exportação, sendo que de 2005 a 2013 o Brasil se encontrava em um processo vigoroso de aumento da produção e da capacidade produtiva. Já nos anos em que a linha pósembarque, que é uma linha para comercialização dos produtos prontos, se tornou maior, o país estava utilizando, em alguma medida, a capacidade ociosa e os estoques para a exportação.

A indústria de transformação é a principal beneficiária desse programa, com participação relativa de $85,29 \%$ dos desembolsos durante o período estudado. No primeiro ano foi ela quem abarcou cerca de 97\% dos recursos; no período de 2000 a 2006 , essa relação se manteve, com algumas variações, na casa dos $90 \%$. Porém, a partir de 2007 , esse valor relativo passou a cair rapidamente, chegando ao patamar mais baixo, no período observado, em 2012, de $71 \%$. Apenas em 2016 o destino dos créditos voltou a ser direcionado em quase sua totalidade, $92 \%$, para a indústria de transformação.

Já em 2017, essa relação ficou em $98 \%$, no entanto os recursos disponibilizados chegam a ser $80 \%$ menores do que os emprestados no ano anterior. Esse fato requer uma atenção especial, dada à capacidade anticíclica da política de financiamento público das exportações, como exposto na revisão bibliográfica, e no período de grave crise em que o Brasil se depara, a diminuição do crédito pode agravar ainda mais a situação econômica do país.

Gráfico 3: Desembolso anual do BNDES para financiamento de exportações, por setor CNAE, em bilhões de dólares — 2000 a 2017.

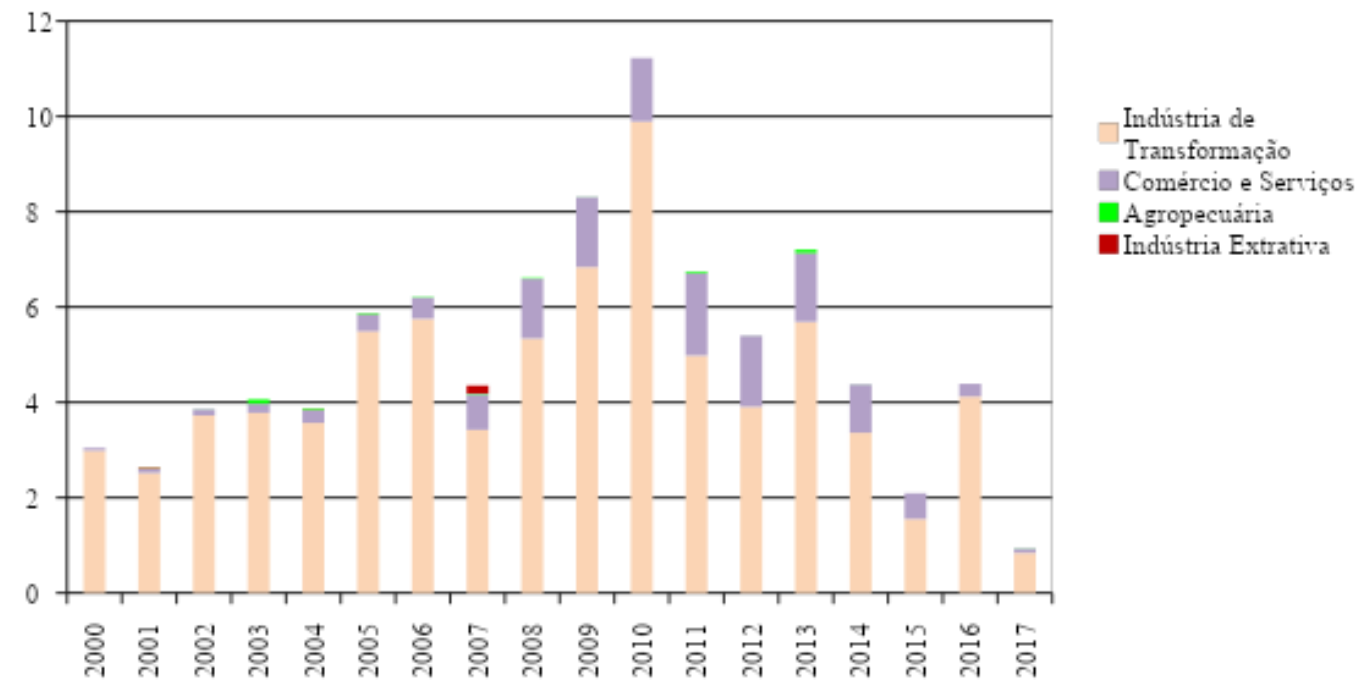

Fonte: BNDES. Elaboração própria. 
Em se tratando dos valores absolutos, a indústria de transformação teve um pico de crescimento dos empréstimos do BNDES-Exim em 2010, abocanhando 9, 893 bilhões de dólares, um crescimento de $45 \%$ em relação ao ano anterior, 2009, que foi de 6,838 bilhões de dólares. No entanto, nos anos $2015 \mathrm{e}$ 2017, os recursos financiados para a indústria de transformação tiveram queda brusca e foram os menores do período analisado, 1,5 bilhão de dólares em 2015 e 841 milhões de dólares em 2017.

O setor de comércio e serviços é o segundo maior destino dos recursos do BNDES-Exim, que pode ser explicado, entre outros fatores, pela linha pós-embarque, que conta com a exportação dos serviços de engenharia com a obrigatoriedade do uso de produtos nacionais. A agropecuária, assim como a indústria extrativa, não foi beneficiada em todos os anos do período em análise. No setor agropecuário, o maior valor de desembolso foi 88 milhões de dólares em 2002, valor quase dez vezes inferior ao menor valor destinado à indústria de transformação no período observado. Já a indústria extrativa foi beneficiada por apenas sete anos e em 2006 o aporte de 166 milhões de dólares foi o maior destinado ao setor.

Os dados por setor Cnae estão disponíveis apenas para o programa pré-embarque e os setores da Cnae que mais utilizaram a linha de financiamento do BNDES-Exim pré-embarque, de 2000 a 2017, são outros equipamentos de transporte (cerca de 33\%) - muito puxado por aeronaves, veículos de reboque e carroceria (em média $26 \%$ ), máquinas e equipamentos (em média $11 \%$ ). Esses três setores abocanharam cerca de $70 \%$ dos recursos da linha de financiamento em questão. Os outros setores, como produtos alimentícios; máquina e aparelho elétrico; metalurgia; equipamentos de informática; eletrônico e ótico; química; entre outros, repartiram os $30 \%$ restantes.

Gráfico 4: Desembolsos do BNDES-Exim pré-embarque por setor Cnae, em milhões de dólares, em períodos selecionados: 2000, 2006, 2012, 2017.

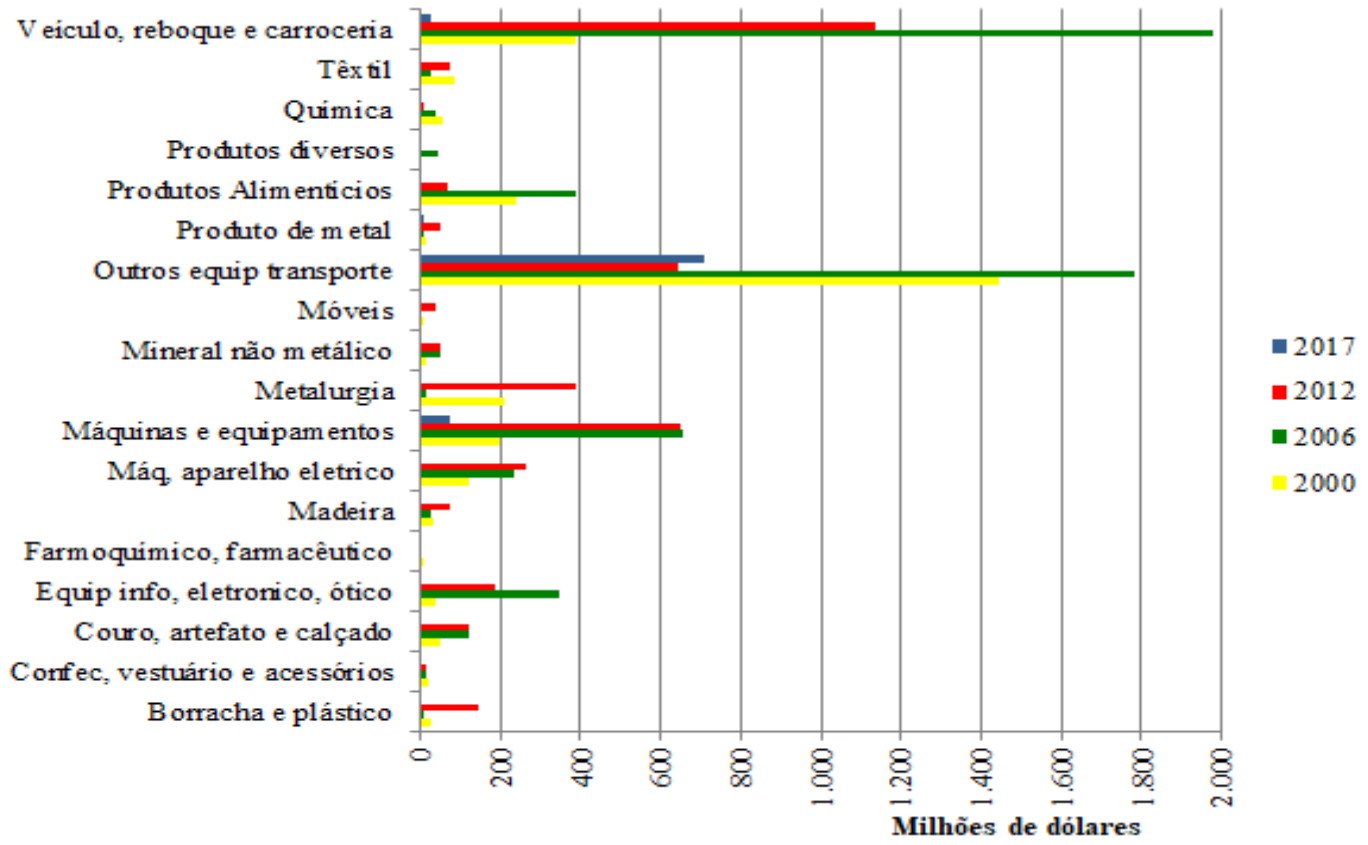

Fonte: BNDES. Elaboração própria.

Em 2017, somente o setor de outros equipamentos de transporte recebeu montante significante desse recurso, cerca de 710 milhões de dólares. Os outros setores aportaram valores entre 75 milhões, como é o caso do setor de máquinas e equipamentos, a 376 mil dólares na metalurgia, que chegou a receber 386 milhões de dólares em 2012.

No entanto nem sempre esses valores foram tão baixos como em 2017. O ano de 2006 foi um ano importante para a maioria dos setores. Foi nesse ano, dentre os selecionados, que se viram os maiores aportes nos setores de veículos, reboque e carroceria (média intensidade tecnológica); outros equipamentos de transporte (média e alta intensidade tecnológica); máquinas e equipamentos (média e 
alta intensidade tecnológica); equipamento de informática, eletrônico e ótico (alta intensidade tecnológica), além de couro, artefato e calçados (baixa intensidade tecnológica), com valores semelhantes aos de 2012. O ano de 2006 foi um ano em que as exportações foram impulsionadas como um todo; inclusive nos setores reportados os maiores desembolsos do BNDES-Exim, mesmo com o estímulo do BNDES ás exportações dos setores de produtos primários e manufaturas intensivas em recursos naturais, cresceram em velocidade maior.

Os anos 2000 e 2012 também foram significativos para a análise e contribuem para reafirmar a dominância dos três setores que, mesmo com o decorrer de quase duas décadas, lideram no recebimento BNDES-Exim pré-embarque: veículos, reboque e carroceria; outros equipamentos de transporte; máquinas e equipamentos. Esses dados são reforçados quando olhamos para os maiores tomadores de empréstimos da linha no período analisado. Porém, desses setores, somente o de veículos, reboque e carroceria teve a relação VTI aumentada, saindo de $7 \%$ em 2000 para $12 \%$ em 2011 . Esses também foram setores que cresceram nas exportações em valores absolutos, embora tenham decrescido em valores relativos.

De acordo com estudo do BNDES (2014), o denominado "Grupo 1 da Lista de Produtos Financiáveis" do BNDES, que são considerados setores estratégicos, que inclui bens de capital e peças, representa em torno de US\$ 30 bilhões exportados anualmente, contra exportações brasileiras totais de US $\$ 225$ bilhões em 2014, por exemplo. Pode ser observado que, em média, o BNDES financiou 17\% das exportações brasileiras de bens de capital e peças entre 2007 e 2014 (BNDES, 2014).

\section{Gráfico 5: Participação do apoio do BNDES-Exim nas exportações totais de bens de capital por segmentos selecionados - 2007-2014 (em \%)}

\begin{tabular}{|c|c|c|c|c|c|}
\hline \multirow{2}{*}{\multicolumn{6}{|c|}{$\%$}} \\
\hline & & & & & \\
\hline 10 & & & & P & 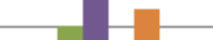 \\
\hline 0 & $\begin{array}{c}\text { Máquinas } \\
\text { industriais ou para } \\
\text { geração de } \\
\text { energia }\end{array}$ & $\begin{array}{l}\text { Máquinas } \\
\text { rodoviárias ou } \\
\text { agricolas }\end{array}$ & $\begin{array}{c}\text { Ônibus, } \\
\text { caminhões, partes } \\
\text { e peças }\end{array}$ & $\begin{array}{l}\text { Outros } \\
\text { equipamentos de } \\
\text { transporte }\end{array}$ & $\begin{array}{c}\text { Demais bens de } \\
\text { capital }\end{array}$ \\
\hline$=2007$ & 5 & 11 & 9 & 11 & 7 \\
\hline$=2008$ & 11 & 10 & 16 & 19 & 7 \\
\hline$=2009$ & 25 & 33 & 37 & 23 & 10 \\
\hline$=2010$ & 23 & 17 & 22 & 33 & 18 \\
\hline$=2011$ & 17 & 13 & 14 & 26 & 2 \\
\hline$=2012$ & 8 & 11 & 12 & 14 & 12 \\
\hline$=2013$ & 19 & 18 & 23 & 22 & 6 \\
\hline$=2014$ & 11 & 8 & 12 & 19 & 1 \\
\hline
\end{tabular}

Fonte: Relatório Efetividade do BNDES, 2014. Elaboração própria.

Em 2010, 48\% dos aviões exportados pela Embraer tiveram apoio do BNDES-Exim. Em 2014 essa relação também foi alta, 47\%. Embora em 2007 não tenha nenhuma participação, nos outros anos foram registrados apoios significativos. De acordo com o gráfico, em 2008 foram exportadas 162 aeronaves pelas Embraer, maior venda do período, e 23 dessas aeronaves possuíam financiamento do BNDESExim. 
Gráfico 6: Participação do apoio do BNDES no total de aeronaves comerciais exportadas pela Embraer - 2007 a 2014, em unidades.

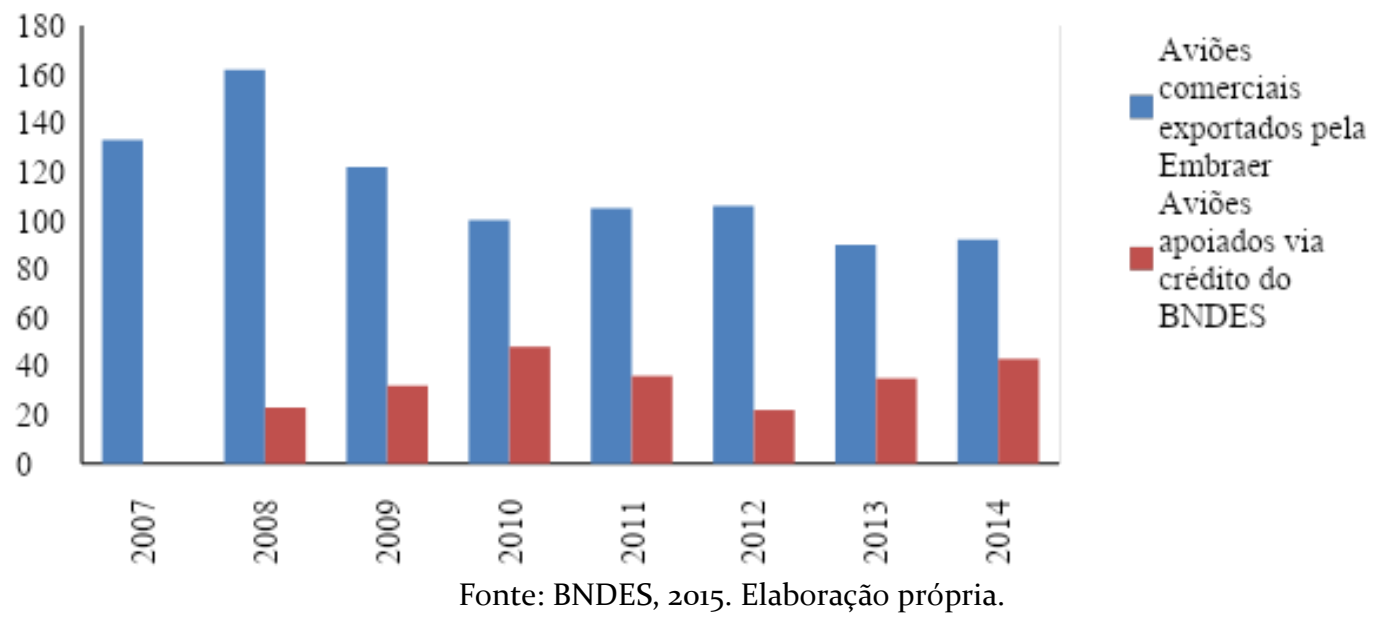

As análises acima, conforme os setores da CNAE, justificam os alvos de atuação prioritária, segundo o BNDES, que são setores de maior valor agregado e intensidade tecnológica. Porém eles representam apenas uma pequena parcela da pauta do comércio exterior brasileiro, que é dominada em sua maioria por commodities agrícolas, minerais e industriais.

Tabela 1: Maiores tomadores de empréstimos do BNDES-Exim Pré-embarque de 2000 a 2017, em reais

\begin{tabular}{|c|c|c|}
\hline & EMPRESA & Total emprestado \\
\hline SP & EMBRAER S.A. & $\mathrm{R} \$ 6.614 .498 .472, \mathrm{oo}$ \\
\hline SP & FORD MOTOR COMPANY BRASIL LTDA. & $\mathrm{R} \$ 6.001 .913 .912,00$ \\
\hline MG & CNH INDUSTRIAL BRASIL LTDA. & $\mathrm{R} \$ 4.289 .617 .156,00$ \\
\hline SP & MERCEDES-BENZ DO BRASIL LTDA. & $\mathrm{R} \$ 4.283 .855 .428,00$ \\
\hline RS & WEG EQUIPAMENTOS ELÉTRICOS S.A. & $\mathrm{R} \$ 4.028 .387 .486,00$ \\
\hline SP & SCANIA LATIN AMERICA LTDA. & $\mathrm{R} \$ 3 \cdot 511.912 .604,00$ \\
\hline SP & GENERAL MOTORS DO BRASIL LTDA. & $\mathrm{R} \$ 2.865 .838 .496,00$ \\
\hline SP & VOLKSWAGEN DO BRASIL INDÚSTRIA DE VEÍCULOS AUTOMOTORES & $\mathrm{R} \$ 2.270 .692 .328,00$ \\
\hline PR & RENAULT DO BRASIL S.A. & $\mathrm{R} \$ 2.217 \cdot 534 \cdot 044,00$ \\
\hline SP & MAN LATIN AMERICA INDUSTRIA E COMERCIO DE VEÍCULOS LTDA. & $\mathrm{R} \$ 2.141 .253 .008,00$ \\
\hline SP & MAHLE METAL LEVE S.A. & $\mathrm{R} \$ 2.062 .435 .636,00$ \\
\hline RS & MARCOPOLO S.A. & $\mathrm{R} \$ 2.018 .313 .353,50$ \\
\hline SC & BRF S.A. & $\mathrm{R} \$ 1.773 .770 .406,00$ \\
\hline MG & FCA FIAT CHRYSLER AUTOMÓVEIS BRASIL LTDA. & $\mathrm{R} \$ 1.747 \cdot 505 \cdot 436,00$ \\
\hline ES & FLEXIBRAS TUBOS FLEXÍVEIS LTDA. & R\$ 1.639.078.400,00 \\
\hline RS & JOHN DEERE BRASIL LTDA. & $\mathrm{R} \$ 1.544 \cdot 128.744, \mathrm{oo}$ \\
\hline SP & TUPY S.A. & $\mathrm{R} \$ 1.428 .555 .253,00$ \\
\hline SP & JBS S.A. & $\mathrm{R} \$ 1.419 .738 .030,63$ \\
\hline PR & VOLVO DO BRASIL VEÍCULOS LTDA. & $\mathrm{R} \$ 1.322 .858 .000,00$ \\
\hline SP & LG ELECTRONICS DO BRASIL LTDA. & $\mathrm{R} \$ 1.142 .453 \cdot 546, \mathrm{oo}$ \\
\hline
\end{tabular}

Fonte: BNDES. Elaboração própria.

A linha de financiamento pós-embarque do programa BNDES-Exim é um financiamento à comercialização que permite que a empresa financie seu importador e receba os recursos à vista, depois de comprovada a exportação. Ao longo deste século até 2017, foram financiados aproximadamente 35 bilhões de dólares e 47 países foram destinatários. Os EUA foram destino de 16 bilhões de dólares (47\% 
do financiamento) em exportações apoiadas pela linha pós-embarque, Angola (9,7\%) e Argentina (9,2\%) com cerca de US\$ 3 bilhões cada, Venezuela com US\$ 2,1 bilhões (6\%), Países Baixos e República Dominicana com US\$1,5 bilhão (4\%). O restante dos países, como Cuba, Equador, Peru, Reino Unido e outros países, possuem valores inferiores a 1 bilhão de dólares cada e, portanto, participações mais baixas. Desse modo, as exportações apoiadas destinaram-se majoritariamente aos Estados Unidos e aos países da América do Sul, seguindo o padrão geral de diversificação geográfica da indústria e dos exportadores que não contaram com apoio público.

Para essa linha de financiamento, o BNDES não disponibiliza dados setoriais. Isso inviabiliza uma análise de quais produtos são mais comercializados por meio do incentivo da linha pós-embarque e de quais níveis tecnológicos teriam essas vendas.

\section{Análise do Modelo: Metodológico e Dados}

A avaliação dos efeitos da política pública de financiamento à exportação não se baseia, aqui neste trabalho, na comparação entre os valores exportados pelas empresas que receberam apoio do programa BNDES-Exim e as que não receberam, ou seja, em âmbito da microeconometria. Os dados de informações referentes a empresas individuais não são disponibilizados, como exposto anteriormente, por questão de sigilo.

Para avaliar o programa público de financiamento à exportação do BNDES, esta seção apresenta um exercício econométrico dividido em duas etapas: na primeira, realizou-se a estimação de um modelo de MQO (Mínimos Quadrados Ordinários) com a variável interessada (dependente), o total de exportações brasileiras trimestrais e a variável dependente principal de créditos à exportação do BNDES-Exim. A etapa seguinte consistiu na estimação de um modelo de regressão GMM (Métodos dos Momentos Generalizados), dada a presença de autocorrelação no modelo, com as mesmas variáveis utilizadas no modelo MQO, além de elas serem defasadas como instrumentos, com o intuito de identificar o efeito da política de financiamento sobre o valor exportado nacional.

Os dados utilizados neste trabalho abrangem o período do primeiro trimestre de $2000(2000 \mathrm{~T} 1)$ até o primeiro trimestre de 2017 (2017T1), e são de frequências trimestrais. As proxys são:

- RENDAPARCEIROS: a renda dos principais países que importam do Brasil. Para a construção dessa variável, renda parceiros, que é uma proxy da demanda externa, foi necessário construir os pesos dos principais parceiros comerciais (importadores) do Brasil do período pelos seus PIBs (bilhões de dólares) (OCDESTAT). Para a construção dos pesos foram considerados os dez principais importadores do Brasil: Estados Unidos, China, Argentina, Países Baixos, Alemanha, Japão, Chile, México, Itália, Reino Unido (FMI; MDIC).

- TCREF: a taxa de câmbio real efetiva (Fonte: IPEADATA);

- PCOM: Índice de preços de commodities (Fonte: FMI/ All Commodity Price Index);

- CREDITO: a variável explicativa foco deste trabalho é o crédito em bilhões de dólares do BNDES para financiar as exportações (Fonte: BNDES).

- EXPORT: a variável dependente são as exportações trimestrais brasileiras em bilhões de dólares (MDIC).

Uma das razões para utilizar o Método dos Momentos Generalizado (GMM) é que enquanto as estimativas por Mínimos Quadrados Ordinários (MQO) frequentemente possuem problemas de autocorrelacão serial, como ocorre neste trabalho, heterocedasticidade e não linearidade, o que é considerado comum nas séries de tempo macroeconômicas, o método GMM fornece estimadores consistentes para a análise de regressão. Cragg (1983) e Hansen (1982), ao analisarem a técnica de estimação por GMM, destacam que a análise das restrições sobreidentificadoras tem papel importante na seleção das variáveis instrumentais para melhorar a eficiência dos estimadores, e, nesse sentido, um teste J é utilizado com o objetivo de testar as propriedades para a validade das restrições sobreidentificadoras.

Para se ter estimadores mais eficientes do que MQO, ou Mínimos Quadrados em Dois Estágios (MQ2E), deve-se levar em consideração as restrições sobre identificadoras, sendo que a matriz de 
ponderação na equação deve ser escolhida de tal forma a permitir que as estimações GMM sejam robustas à possível presença de heterocedasticidade e de autocorrelacão (WOOLDRIDGE, 2001). O autor destaca que os coeficientes estimados por GMM são consistentes apenas se as variáveis instrumentais utilizadas na análise forem exógenas. O autor enfatiza ainda que as estimativas GMM podem sofrer com problemas de amostras finitas, especialmente quando se adicionam muitas condições de momento que não adicionam muita informação à estimação. (VIEIRA; DAMASCENO, 2016). Hansen (1982), ao analisar o estimador GMM para séries de tempo, enfatiza que este permite a adição de condições de momento ao assumir que valores passados das variáveis explicativas, ou mesmo valores passados da variável dependente, são não correlacionados com o termo de erro, mesmo não estando presentes diretamente no modelo (VIEIRA; DAMASCENO, 2016).

As estimações dos modelos por GMM foram feitas incluindo cinco defasagens das variáveis explicativas, além da variável dependente exportações (EXPORT), defasada também em cinco trimestres. O número de defasagens dos instrumentos utilizados na estimação do modelo GMM foi 5, e tal escolha foi baseada na análise da Estatística J e em sua probabilidade, em que a hipótese nula a ser testada é a de que as condições sobreindentificadoras (conjunto de instrumentos) são válidas, e nesse sentido a estimação dos modelos GMM com um menor número de defasagens (foi testado para 4, 3, $2 \mathrm{e}$ 1 defasagens) fornecia resultados insatisfatórios, ou seja, Estatísticas J com probabilidade menor que 5\%, o que invalidaria a utilização desses conjuntos de instrumentos.

A estimação do modelo de variações nas exportações, dada a variação de créditos do BNDES para o financiamento das exportações, para a economia brasileira com dados trimestrais de 200oT1 a 2017T1, tem por base as seguintes equações para investigar o papel do crédito do BNDES nas exportações brasileiras:

$$
\text { EXPORT }_{t}=\beta \mathrm{O}+\beta_{1} \text { CREDITO }_{t} \beta_{2} \text { PCOM }_{t} \beta_{3} \text { RENDAPARCEIROS }_{t} \beta_{4} \text { TCREF }_{t} U_{t}(1)
$$

A tabela abaixo sistematiza os testes de estacionariedade das séries de tempo para que possam ser utilizadas na equação apenas as séries estacionárias. 
Tabela 2: Testes de Estacionariedade-ADF, PP, KPSS e DF-GLS - 2000T1 a $2017 \mathrm{~T} 4$.

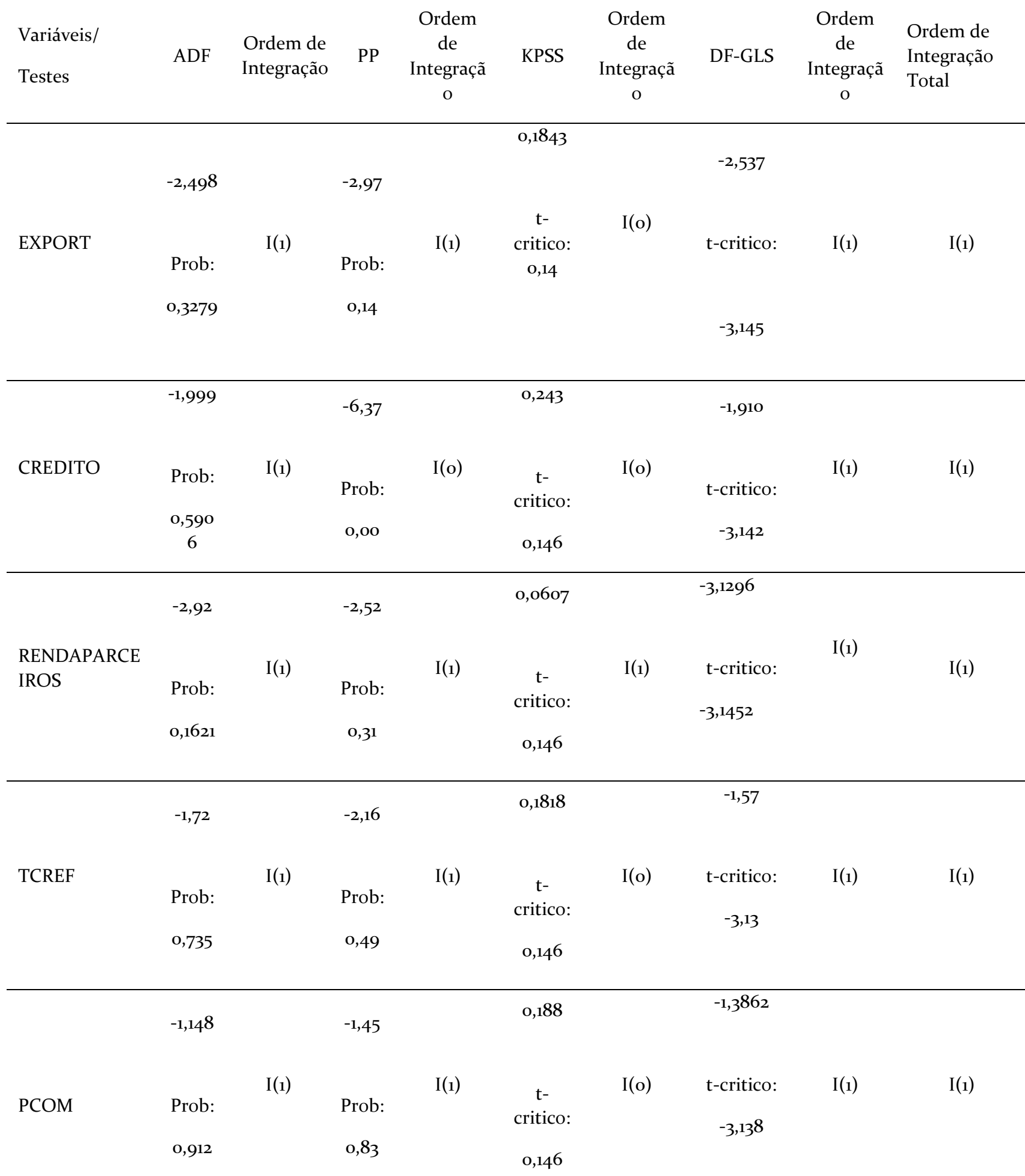

Notas: ADF, PP e DF-GLS estatística t e KPSS estatística LM. Hipótese nula para ADF, PP e DF-GLS = Série possui Raiz Unitária/ série não estacionária. Hipótese nula para KPSS = Série é Estacionária. I(1) indica integrada de ordem um e não estacionária; I(o) indica integrada de ordem zero e estacionária. Os valores dos t-críticos são a 5\%, exceto os assinalados com $1 \%$ e $10 \%$.

Os resultados dos testes ADF, Phillips-Perron (PP), KPSS e DF-GLS indicam que as variáveis usadas nesse modelo são não estacionárias, ou seja, possuem raiz unitária. Sendo assim, é necessário 
que se usem as variáveis em questão em primeira diferença. Desse modo, todas as variáveis, a partir daqui, serão analisadas em primeira diferença. A equação do MQO então será:

DEXPORT $_{t=\beta O+} \beta_{1}$ DCREDITO $_{t_{+}} \beta_{2}$ DPCOM $_{t+} \beta_{3}$ DRENDAPARCEIROS $_{t_{+}} \beta_{4} \mathrm{D}^{\text {TCREF }}{ }_{t+} \varepsilon_{(2)}$

$\mathrm{Na}$ nova equação do modelo em GMM, são utilizadas, como instrumento, cinco defasagens feitas das variáveis explicativas em primeira diferença, além da variável dependente variação das exportações (DEXPORT), defasada também em cinco trimestres.

Tabela 3: Estimação MQO e GMM - Variação nas exportações brasileiras

\begin{tabular}{|c|c|c|}
\hline Modelo & MQO & GMM \\
\hline DCREDITO & 1.517598 & 1.677742 \\
\hline Prob & $(0.0064)^{* * *}$ & $(0.0000)^{* * *}$ \\
\hline DPCOM & 246.8004 & $315 \cdot 5361$ \\
\hline Prob & $(0.0000)^{* * *}$ & $(0.0000)^{* * *}$ \\
\hline DRENDAPARCEIROS & 0.005741 & 0.016539 \\
\hline Prob & $(0.2679)$ & $(0.0781)^{*}$ \\
\hline DTCREF & $25 \cdot 35880$ & 31.86852 \\
\hline Prob & $(0.6857)$ & $(0.5976)$ \\
\hline $\mathbf{R}^{2}$ & 0.399526 & 0.331758 \\
\hline F-Stat & 10.47927 & - \\
\hline Prob F-Stat & 0.000001 & - \\
\hline Teste BG - Prob & 0.0000 & - \\
\hline Teste White - Prob & 0.6554 & - \\
\hline J-Statistics & - & 13.67382 \\
\hline Prob. J. Statistics & - & $(0,622999)$ \\
\hline Teste de Endogeneidade - Prob & - & (o.8791) \\
\hline
\end{tabular}

Notas: ${ }^{*},{ }^{* *} \mathrm{e}^{* * *}$ indicam significância estatística a 10\%, 5\% e 1\%. Não foram reportados os coeficientes da constante. Modelo Estimado com a Correção de Newey-West. Teste BG de Autocorrelação - Hipótese Nula de Ausência de Autocorrelacão. Teste White de Homocedasticidade - Hipótese Nula de Homocedasticidade. Teste de Endogeneidade - Difference in J-stats Hipótese Nula: Regressores Exógenos.

O resultado do Teste White indica que o modelo é homocedástico, ou seja, não tem a presença de heterocedasticidade. Já o Teste de BG de ausência de autocorrelação indica a presença de autocorrelação, o que justifica o uso do método GMM, já que ele tem ganhos perante o MQO pela presença de autocorrelação no modelo acima rodado. A autocorrelação detectada pelo teste BG foi corrigida pelo HAC. Já a estatística J (hipótese nula - Ho desse teste é a de que o conjunto de instrumentos é válido) indica que os instrumentos são válidos (deve-se aceitar Ho quando a 
probabilidade da estatística J tiver alta, superior a 0,05 e 0,10 , para que o conjunto de instrumentos seja válido). Sendo válido deverá usar o modelo GMM, dado seu ganho em relação ao MQO.

Também foi feito o teste de endogenia para ver se as variáveis explicativas estão correlacionadas com o erro. A hipótese nula (Ho) desse teste é de que as variáveis são exógenas, então, para aceitar, a probabilidade de Difference in J-statdeve ser maior que 0,05 , não rejeitando que as variáveis do modelo são exógenas. O teste de endogeneidade revela que o conjunto de regressores é exógeno, as variáveis explicativas não estão correlacionadas com os resíduos.

Sendo válido e tendo ganho em relação ao MQO, já que este tem problema de autocorrelação que causa perda de eficiência, serão considerados na análise os resultados do modelo GMM. As proxys variação dos preços de commodities e variação da renda dos parceiros (demanda externa) possuem significância estatística, a primeira a $1 \%$ e a segunda a 10\%. Elas apresentam sinais positivos e valores esperados.

Já a estatística DTCREF (variação da taxa de câmbio real efetiva) não apresenta significância estatística nesse modelo, o que contraria a expectativa e a literatura de comércio internacional que defendem a significância das variações da taxa de câmbio real efetiva nas variações dos valores das exportações. Segundo os autores Miguez et al. (2018), no entanto, esse resultado é compreensível, já que se trata de produtos mais tecnológicos, e, portanto mais diferenciados, que são menos dependentes do câmbio para a venda externa.

O impacto da variação do financiamento às exportações brasileiras por meio do crédito do BNDES sobre a variação do montante de exportações possui significância estatística até mesmo a 1\% no modelo GMM. A estimativa em GMM indica que cada variação de 1 bilhão de dólares no crédito concedido às empresas com fins de exportação pelo BNDES-Exim gera uma variação de 1,677 milhão de dólares nas exportações brasileiras, ou ainda, a cada variação de 1 dólar emprestado aumenta as exportações em 1 dólar e 67. Esse resultado corrobora a tese deste artigo de que é essencial o apoio governamental através de financiamento às exportações brasileiras para o aumento destas e de suas positivas consequências sobre o comércio internacional e o desenvolvimento econômico do país.

\section{Considerações Finais}

As exportações possuem um papel estratégico como um mecanismo de desenvolvimento econômico. Apesar do crescimento verificado nos últimos anos nas exportações brasileiras, chama atenção também a perda de importância relativa dos produtos manufaturados na pauta brasileira, em especial dos produtos mais intensivos em tecnologia e conhecimento.

Nesse contexto, as políticas de apoio à exportação ganham importância, tanto para sustentar o crescimento das exportações como para apoiar a maior participação dos produtos de maior intensidade tecnológica e geração de valor. Os programas públicos de financiamento à exportação assumem papel importante dentro dessa estratégia, ao exibirem funções complementares aos mecanismos privados de financiamento, seja para a concessão com prazos maiores para empresas que possuem ciclo de desenvolvimento/ produção e comercialização mais longos, ou ainda para direcionamento dos recursos aos setores mais intensivos em tecnologia e conhecimento.

Com o objetivo de realizar uma avaliação do programa público de financiamento à exportação do BNDES, estimaram-se os modelos MQO e GMM e os resultados obtidos indicaram que a cada variação de 1 bilhão de dólares no crédito as exportações variam em US\$1,6 bilhões o valor das exportações brasileiras, um impacto significativo e bastante relevante.

Neste trabalho também se aponta que a linha de financiamento de exportações do BNDES apoiou mais intensamente os setores de maior geração de valor, maior intensidade tecnológica e menor participação na pauta exportadora nacional, embora tenha apoiado também setores tradicionais que possuíam alguma vantagem estratégica. $\mathrm{O}$ setor de produtos alimentícios e bebidas, por exemplo, não faz parte dos setores de maior oportunidade tecnológica e de maior elasticidade-renda da demanda. A explicação razoável para o apoio a esse setor pode ser pelas estratégias de internacionalização que suas 
empresas estão seguindo para ampliar a presença em diversos mercados com produtos de maior agregação de valor através de processamento industrial, inovação química e biotecnologia.

Outra relação encontrada é a de que as exportações de maiores intensidades tecnológicas aumentaram ao longo do tempo, indicando um possível impacto do programa, embora as vendas ao exterior dos setores de produtos primários e manufaturas em recursos também tenham aumentado e em maior velocidade. Diante disso, suspeita-se, que o programa, em termos líquidos, não foi suficiente para contrapor uma força ou tendência maior que o efeito China.

No entanto, um ponto em especial deste trabalho deve ser alvo de preocupação, a reversão de tendência. Além das empresas que tiveram problemas judiciais em operações como a Lava-Jato diminuírem ou pararem de usar os créditos, nos últimos anos, os valores desembolsados para o apoio das exportações têm caído consideravelmente. Esse fato requer uma atenção especial, dada à capacidade anticíclica da política de financiamento público das exportações observada ao longo de todo o trabalho e o período de profunda crise em que o Brasil se depara em que a diminuição do crédito pode agravar ainda mais a situação econômica do país.

\section{Referências}

BLUMENSCHEIN, F.; DE LEON, F. L. L. Uma análise de desempenho e da segmentação do sistema de crédito à exportação no Brasil. In: PINHEIRO A.C., MARKWALD R. e PEREIRA L. V. (orgs.). O desafio das exportações. Rio de Janeiro: BNDES, 2002.

BNDES. Evolução dos Desembolsos. Desembolso Mensal nas modalidades pós-embarque e pré-embarque por setor CNAE. Disponível em:

$<$ http://bndes.gov.br/wps/portal/site/home/transparencia/centraldedownloads> Acesso em: 30 mar. 2018.

Institutional presentation. Rio de Janeiro: BNDES, 2014.

Relatório Anual de 2009. Disponível em:

<https://www.bndes.gov.br/SiteBNDES/export/sites/default/bndes_pt/Galerias/Arquivos/empresa/Rel Anual/ra2009/relatorio_anual2009.pdf $>$. Acesso em: 20 dez. 2017.

. Relatório de Efetividade 2007-2014: A Contribuição do BNDES para o Desenvolvimento Nacional. Rio de Janeiro: BNDES, 2015. Disponível em:

<https://www.bndes.gov.br/wps/portal/site/home/transparencia/estatisticas>. Acesso em: 30 abr. 2017.

BRESSER-PEREIRA, L.C.; OREIRO, J.L; MARCONI, N. Macroeconomia desenvolvimentista: Teoria e política econômica do novo desenvolvimentismo. Rio de Janeiro: Elsevier, 2016.

CATERMOL, F. BNDES-exim: 15 anos de apoio às exportações brasileiras. Revista do BNDES, Rio de Janeiro, V.12, N.24, P. 3-30, DEZ.2005.

CNI, Confederação Nacional das Indústrias. Os problemas da empresa exportadora brasileira. Brasília: CNI, 2008.

CRAGG, J. G. (1983) "More efficient estimation in the presence of heteroscedasticity of unknow form. Econometrica, Vol. 51, no 3, p. 751-763.

CUNHA, A. M.; PRATES, D. M.; CARVALHO, C. E. O Sistema Nacional de Fomento: Formato Atual e Propostas de Reforma. Análise Econômica, Porto Alegre, v. 34, p. 269-300, 2016. 
GALETTI, J. R.As Políticas Públicas De Financiamento À Exportação No Brasil (BndesExim E Proex): Características E Efeitos Sobre As Exportações Das Empresas Industriais Brasileiras. UNICAMP, 2010.

GALETTI, J. R.; HIRATUKA,C. Financiamento às exportações: uma avaliação dos impactos dos programas públicos brasileiros. Rev. Econ. Contemp., Rio de Janeiro, v. 17, n. 3, p. 494-516, set-dez/2013.

GARÓFALO, E; TEIXEIRA, M.G.R. (1995): Uma proposta para dinamizar o financiamento às exportações brasileiras. FUNCEX, Texto para Discussão ㄲo116, Rio de Janeiro.

GIOMO, D.; BARCELOS, M. A. COMÉRCIO INTERNACIONAL E ESPECIALIZAÇÃO PRODUTIVA BRASILEIRA. In: 1o Encontro da Nacional de Economia Industrial e Inovação, 2016.

HANSEN, L. P. (1982) "Large sample properties of generalized method of moments estimators". Econometrica Vol. 50, no 4, p. 1029-1054.

HAUSMANN, R.; RODRIK, D. Economic development as self-discovery. Journal of development economics, v. 72, n. 2, p. 603-633, dez. 2003.

INTERNATIONAL MONETARY FUND. World Economic Outlook Database. IMF: Washington, 2017. Acesso em abril de 2017: http://www.imf.org/external/np/res/commod/index.aspx

IPEADATA. INSTITUTO DE PESQUISA ECONOMICA APLICADA, 2017. Acesso em abril de 2017: http://ipeadata.gov.br/ListaSeries

LALL, S. The Technological Structure and Perfomance of Developing Country Manufactured Exports, 1985 - 1998. Working paper number 44, 2000. QEH Working Paper Series.

MAZZUCATO, M.; PENNA, C. Beyond market failures: The market creating and shaping roles of State investment banks. Levy Institute Working Paper 831, January, 2015. Annandale-on-Hudson: Levy Institute.

MIGUEZ, T; DAUDT, G; PLATTEK, B; WILLCOX, L; SCHMITT, S; Uma visão de política industrial para o Brasil: resultados a partir de uma proposta de matriz tecnológica. In: ENEI, 2018. Blucher, p. 834-852.

MOREIRA, U. Teorias do comércio internacional: um debate sobre a relação entre crescimento econômico e inserção externa. Revista de Economia Políticaz2 (2), 2012.

NAIDU, G. M. et al. An export promotion model for India: implications for public policy. International business review, v. 6, n. 2, p. 113-125, Apr. 1997.

NASCIMENTO, C. A.; CARDOZO, S. A.; CUNHA, S.F.E. Reprimarização ou dependência estrutural de commodities? O debate em seu devido lugar. In: XIV Encontro Nacional de Economia Política, 2009, São Paulo. Anais do XIV Encontro Nacional de Economia Política, 2009.

OECD STATISTICS (2017) Disponível em: http://stats.oecd.org/

PIANTO, D. M.; CHANG, L.; O Potencial Exportador e as Políticas de Promoção das Exportações da APEX-Brasil. In: João A. De Negri; Bruno Araújo (org.). As Empresas Brasileiras e o Comércio Internacional. Brasília: IPEA, 2006.

RODRÍGUEZ, O. O estruturalismo latino-americano. Tradução Maria Alzira Brum Lemos. Rio de Janeiro: Civilização Brasileira, 2009. 
RODRIK, D. Industrial development: stylized facts and policies. Cambridge, 2006. Disponível em http://www.hks.harvard.edu/fs/drodrik/research.html.

SERINGHAUS, F. H.; BOTSCHEN, G. Cross-national comparison of export promotion services: the views of Canadian and Austrian companies. Journal of international business studies, v. 22, Issue 1, p. 115-133, 1991.

SECEX/MDIC. Secretaria Do Comércio Exterior Do Ministério Do Desenvolvimento, Indústria E Comércio Exterior. Balança Comercial Brasileira: dados consolidados. Disponível em:

http://www.mdic.gov.br//sitio/interna/interna.php?area=5\&menu=4761. Acesso em: abril de 2018.

SMITH, A. A riqueza das Nações. Ano: 1776. Tradução: Luiz João Baraúna. São Paulo: Abril Cultural (Coleção Os economistas), $2^{\mathrm{a}}$ ed., 1985.

THIRLWALL, A. P. A plain man's guide to Kaldor's Growth Laws. Journal of Post-Keynesian Economics, v. 5, p. 345-358, 1983.

UN COMTRADE. United Nations Commodity Trade Statistics Database. Statistics Division. Disponível em: http://comtrade.un.org/db/. Acesso em: maio de 2018.

UNCTAD. The Role of Development Banks in Promoting Growth and Sustainable Development in the South. Geneva: United Nations Conference on Trade and Development, 2016.

VEIGA, P. M.; IGLESIAS, R. M. A institucionalidade da política brasileira de comércio exterior. In: PINHEIRO A.C., MARKWALD R. e PEREIRA L. V. (orgs.). O desafio das exportações. Rio de Janeiro: BNDES, 2002.

VIEIRA, F. V.; DAMASCENO, A. O. Desalinhamento cambial, volatilidade cambial e crescimento econômico: uma análise para a economia brasileira (1995-2011). Revista de Economia Política, vol. 36, no 4 (145), pp. 704-725, outubro-dezembro/2016.

WEBBER, S. L.; DATHEIN, R. A atuação do BNDES-Exim como fortalecedor das exportações brasileiras no período 200o-2012. Porto Alegre. Texto para Discussão: UFRGS, Faculdade de Ciências Econômicas, n. $04 / 2014$.

WOOLDRIDGE, J. M. (2001) "Applications of generalized method of moments estimation". Journal of Economic Perspectives, Vol. 15, no 4, p. 87-100.

Recebido em 12.11.18

Aprovado em 19.06.19 
ANEXO A: LISTA DE PRODUTOS E CÓDIGOS SEGUNDO A CLASSIFICAÇÃO DE LALL

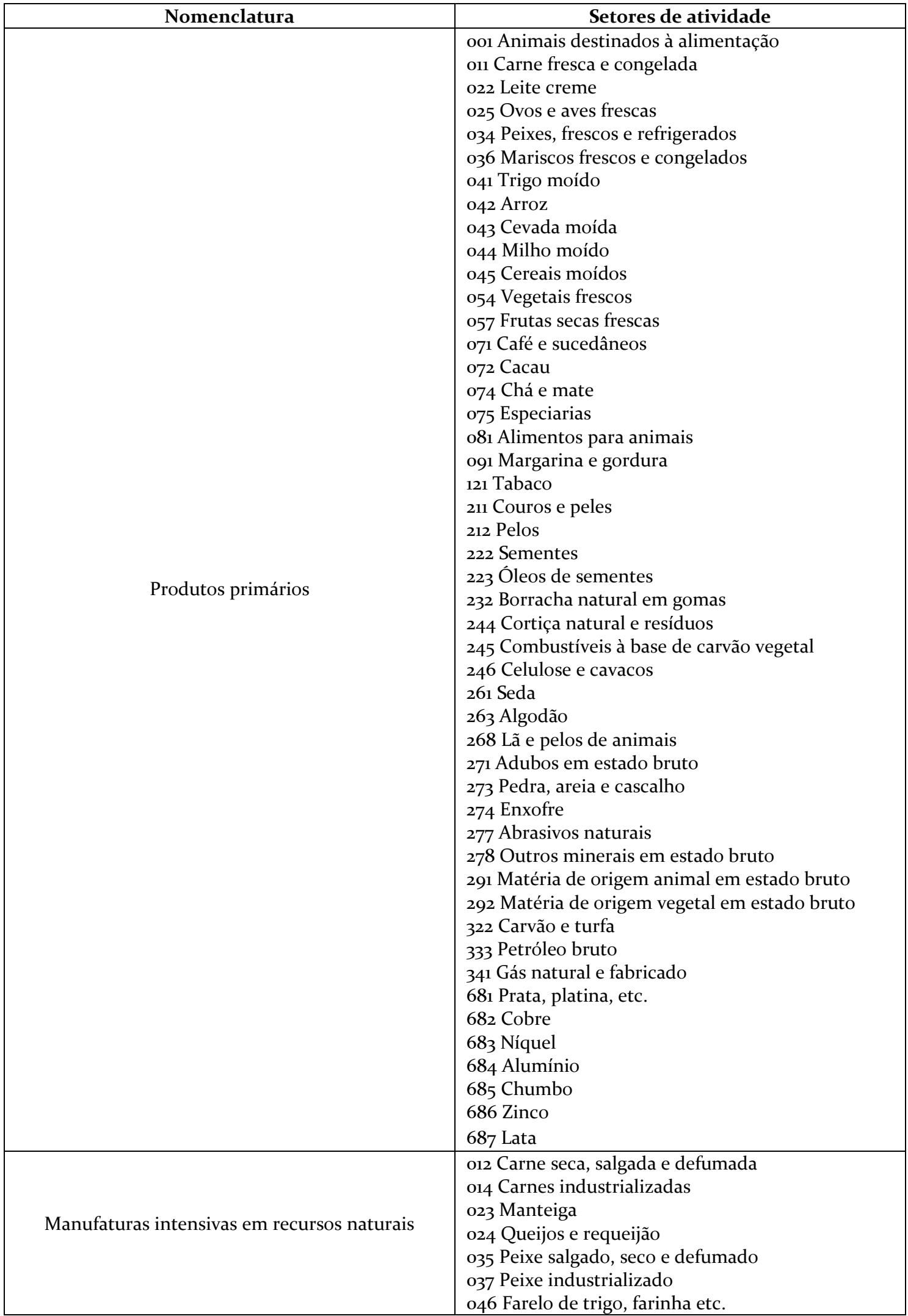

(Continua) 
(Continuação)

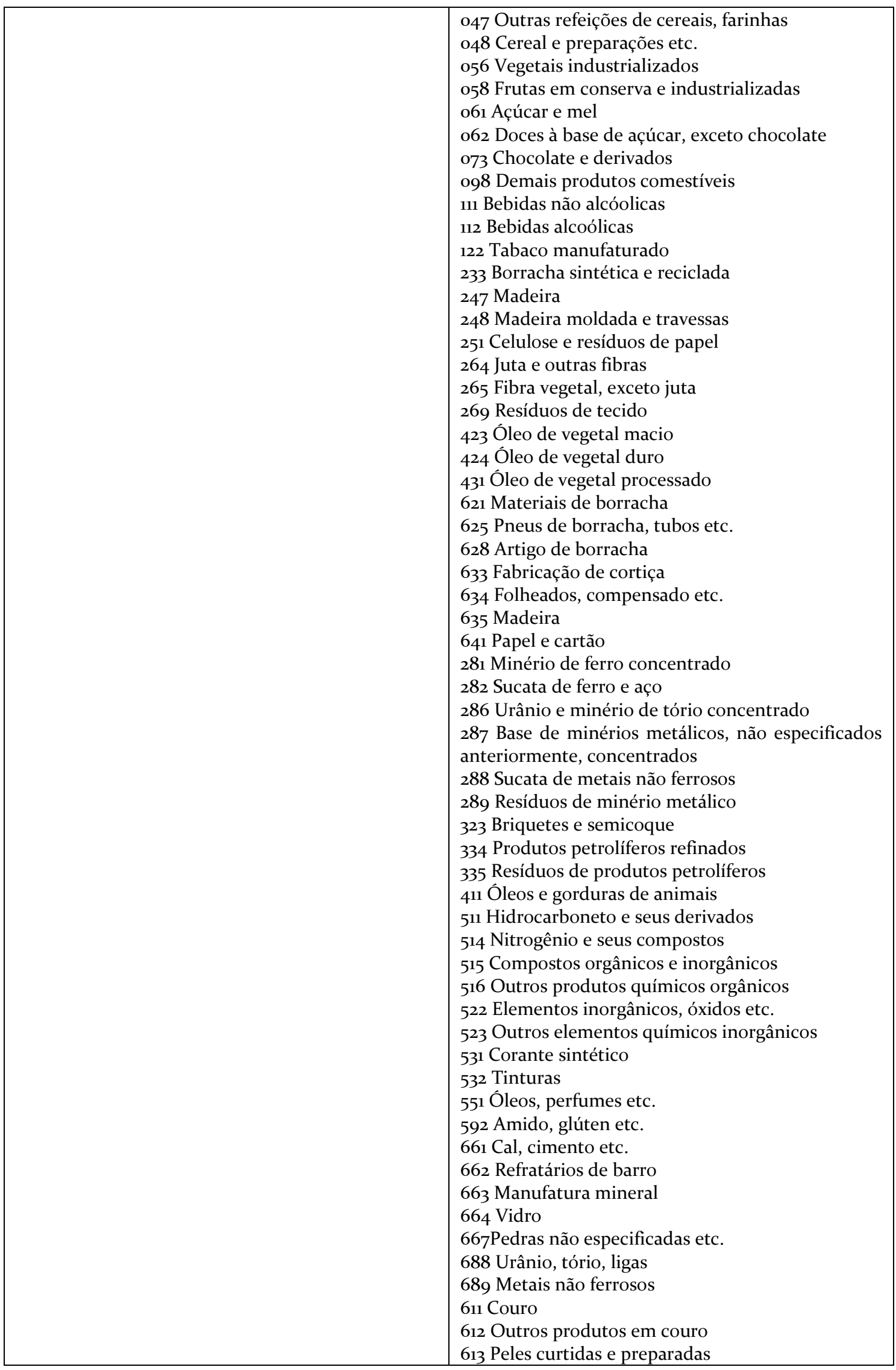

(Continua) 
(Continuação)

\begin{tabular}{|c|c|}
\hline Manufaturas de baixa intensidade tecnológica & $\begin{array}{l}651 \text { Fios têxteis } \\
652 \text { Tecidos de algodão } \\
654 \text { Outros tecidos } \\
655 \text { Tecidos de malha } \\
656 \text { Tecidos, laços de renda etc. } \\
657 \text { Produtos têxteis especiais } \\
658 \text { Artigos têxteis não especificados } \\
659 \text { Tapetes etc. } \\
831 \text { Artigos de viagem } \\
842 \text { Agasalhos masculinos, exceto de malha } \\
843 \text { Agasalhos femininos, exceto de malha } \\
844 \text { Peças de vestuário, exceto de malha } \\
845 \text { Agasalhos, exceto de elástico } \\
846 \text { Vestuário de malha } \\
847 \text { Outros vestuários } \\
848 \text { Chapelaria e artigos similares } \\
851 \text { Calçado } \\
642 \text { Papel, manufaturas etc. } \\
665 \text { Derivados de papeis } \\
666 \text { Olaria } \\
673 \text { Formas em aço e ferro etc. } \\
674 \text { Folhas de aço e ferro em chapas } \\
675 \text { Tiras de ferro e aro de aço } \\
676 \text { Trilhos em aço e ferro } \\
677 \text { Ferro ou aço não isolado } \\
679 \text { Ferro, fundição em aço, forjaria e estamparia } \\
\text { no estado bruto } \\
691 \text { Peças e estruturas não especificadas } \\
692 \text { Tanques de metal, caixas etc. } \\
693 \text { Produtos de arame não eletrificado } \\
694 \text { Pregos, porcas em aço etc. } \\
695 \text { Ferramentas } \\
696 \text { Talheres } \\
697 \text { Equipamentos à base de aço } \\
699 \text { Base de metal não especificada } \\
821 \text { Partes móveis } \\
893 \text { Obras em plásticos não especificadas } \\
894 \text { Brinquedos, artigos esportivos etc. } \\
895 \text { Artigos de escritório } \\
897 \text { Utensílio de prata e joias em ouro } \\
898 \text { Instrumentos musicais } \\
899 \text { Outros produtos manufaturados }\end{array}$ \\
\hline \multirow[b]{2}{*}{ Manufaturas de média intensidade tecnológica } & $\begin{array}{l}\text { Automobilística } \\
781 \text { Motor de ônibus } \\
782 \text { Caminhões } \\
783 \text { Veículos rodoviários } \\
784 \text { Peças e acessórios para motores veiculares } \\
785 \text { Ciclomotores e veículos não motorizados }\end{array}$ \\
\hline & $\begin{array}{l}\text { Processos } \\
266 \text { Fibras sintéticas } \\
267 \text { Outras fibras } \\
512 \text { Álcool, fenóis etc. } \\
513 \text { Ácido carboxílico etc. } \\
533 \text { Pigmentos, tintas etc. } \\
553 \text { Perfumaria, cosméticos etc. } \\
554 \text { Sabão para limpeza etc. } \\
562 \text { Adubos fabricados } \\
572 \text { Explosivos pirotécnicos }\end{array}$ \\
\hline
\end{tabular}

(Continua) 
(Continuação)

\begin{tabular}{|c|c|}
\hline & $\begin{array}{l}582 \text { Produtos de condensação etc. } \\
583 \text { Produtos à base de polímeros } \\
584 \text { Derivativos de celulose etc. } \\
585 \text { Material plástico não especificado } \\
591 \text { Pesticidas e desinfetantes } \\
598 \text { Demais produtos químicos } \\
653 \text { Tecidos de fibras sintéticas ou artificiais } \\
671 \text { Ferro-gusa } \\
672 \text { Ferro e formas de aço primária } \\
678 \text { Ferro em tubos, mangueiras etc. } \\
786 \text { Reboques não motorizados não especificados } \\
791 \text { Veículos de transporte ferroviário } \\
882 \text { Fotos, artigos de cinema }\end{array}$ \\
\hline & $\begin{array}{l}\text { Engenharia } \\
711 \text { Caldeiras a vapor e peças } \\
713 \text { Pistão de motores de combustão interna e suas } \\
\text { partes } \\
714 \text { Motores não especificados } \\
721 \text { Tratores e máquinas agrícolas } \\
722 \text { Tratores não rodoviários } \\
723 \text { Equipamentos para engenharia civil etc. } \\
724 \text { Máquinas para têxteis e couro } \\
725 \text { Máquinas para fabricar papel etc. } \\
726 \text { Máquinas para tinturas } \\
727 \text { Máquinas industriais para alimentos } \\
728 \text { Outras máquinas industriais } \\
736 \text { Máquinas e ferramentas para metais } \\
737 \text { Máquinas de ferramentas para metais não } \\
\text { especificadas } \\
741 \text { Equipamentos para aquecimento e refrigeração } \\
742 \text { Bombas para líquidos etc. } \\
743 \text { Bombas, centrífugas etc. } \\
744 \text { Equipamentos de movimentação } \\
745 \text { Ferramentas mecânicas não elétricas não } \\
\text { especificadas } \\
749 \text { Máquinas elétricas de corrente contínua } \\
762 \text { Receptores de rádio e difusão } \\
763 \text { Gravadores de som e fonógrafos } \\
772 \text { Peças de interruptores não especificados etc. } \\
773 \text { Equipamentos de distribuidores elétricos } \\
775 \text { Equipamentos domésticos não especificados } \\
793 \text { Navios, barcos etc. } \\
812 \text { Sanitários, } \\
\text { aquecimento e acessórios } \\
872 \text { Instrumentos médicos não especificados } \\
873 \text { Metros e contadores não especificados } \\
884 \text { Mercadorias ópticas não especificadas } \\
885 \text { Relógios } \\
951 \text { Armas de guerra e munições }\end{array}$ \\
\hline Manufaturas de alta intensidade tecnológica & $\begin{array}{l}716 \text { Rotores de usina elétrica } \\
718 \text { Outras máquinas geradoras de energia } \\
751 \text { Máquinas de escritório } \\
752 \text { Equipamentos de processamento de dados } \\
\text { automático } \\
759 \text { Máquinas para escritório } \\
761 \text { Receptores de televisão }\end{array}$ \\
\hline
\end{tabular}

(Continua) 
(Continuação)

764 Equipamentos de telecomunicação não especificado 771 Máquinas de energia elétrica não especificadas

774 Equipamento elétrico movido à bateria

776 Transistores, válvulas etc.

778 Máquinas elétricas não especificadas

524 Material radioativo etc.

541 Medicamentos e produtos farmacêuticos

712 Motores e turbinas a vapor

792 Aeronaves

871 Instrumentos ópticos

Fonte: UNCOMTRADE. Elaboração própria. 